Espacio, Tiempo y Forma, Serie VII, H. a del Arte, t. 18-19, 2005-2006, págs. 237-279

\title{
Comillas, paisaje cultural Comillas, cultural landscape
}

\author{
RAMÓN RODRÍGUEZ LLERA
}

\section{RESUMEN}

Comillas conserva un importante legado cultural que hasta hace pocas décadas se mantuvo perfecto respecto a su estado original. Pero como ocurre con el caso de tantos sitios monumentales, la villa es deudora y al tiempo víctima de su propio patrimonio.

Comillas goza además de un paisaje excepcional que constituye la causa básica de su permanencia como enclave residencial privilegiado, lo cual se explica desde un doble factor: la belleza natural del lugar como motivo de la elección del sitio de la ciudad, también el entorno marítimo, costero y de tierra adentro, y que determina la vista desde donde la villa es reconocida como parte de un magnífico panorama pintoresco.

El territorio de Comillas se concreta en un espacio, el propio de la villa histórica y su periferia próxima, que sería uno más de los característicos de la región si no hubiera conocido en un tiempo relativamente breve, apenas medio siglo, una intensa ocupación, cultural y artísticamente excepcional, de tal manera que las transformaciones del paisaje de la villa acaecidas en las tres últimas décadas del siglo diecinueve y los primeros años del veinte no sólo modificaron sino que determinaron el devenir de Comillas hasta la actualidad, cuya memoria cultural está

\section{ABSTRACT}

Comillas conserves an important cultural legacy that has been perfectly preserved untill a few decades. But as it usually happens with many monumental sites, the villa has become a victime of its own patrimony.

In addition, Comillas enjoys of an exceptional landscape that constitutes the basic cause of its permanence as priviledged residential area, which is explained from a double factor: the natural beauty of the place like reason for the election of the site of the city, also the marine and its coast, inland sourrandings that determine the Vista from where the villa is recognized like part of a magnificent colorful panorama. The territory of Comillas takes shape in a space, own of the historical villa and its next periphery, that would be one more of the characteristic ones of the region if it had not known in a relatively brief time, hardly half century, an intense occupation, cultural and artistic talking exceptional, in such a way that the transformations of the landscape of the villa happened in the three last decades of the nineteen century and first years of the twenty not only modified but also determined Comillas until the present time, whose cultural memory is link in a very special way to the facts of that moment of its past. 
ligada de manera muy especial a los hechos de ese momento de su pasado. Comillas está excepcionalmente ligada a su memoria, su fama se remite a un tiempo de esplendor artístico, que es básicamente un tiempo del pasado. Memoria del pasado, pues. Pero tal visión retrospectiva no debe inducirnos a engaños. Ese pasado determina y condiciona positivamente el presente. Es un bien, no una carga insoportable.

De los espacios culturales de Comillas sabemos casi todo lo necesario, lo más relevante. Su origen. Sus protagonistas. Sus hechos. La importancia de los mismos, su éxito y su primera extinción.

También asistimos al momento de su reconocimiento posterior que le adjudica el timbre de la cultura patrimonial, entendido como bien colectivo generador de la fase actual, caracterizada por el disfrute turístico y popular de ese patrimonio.

En la actualidad la villa de Comillas esta alejada de sus funciones originales, están ausentes los protagonistas que fueron la causa de su éxito y fama, por lo que lo que prima en ella es su valor como "espacio de la memoria».

Retrospectivamente, es comúnmente aceptado que el «tiempo» de Comillas coincide básicamente con las tres últimas décadas del siglo diecinueve, o, contado según los protagonistas directos determinantes, con el tiempo de los dos primeros marqueses titulados "de Comillas", Antonio López López y su hijo Claudio López Bru. La intervención sucesiva de ambos sobre la villa natal supone una suma de intenciones, de actuaciones artísticas y arquitectónicas, de inversiones económicas, en definitiva, de

un proyecto ambiciosísimo, único en su momento, generoso e, incluso, visionario, cuyas huellas permanecen en la imagen de la villa. Todos los hechos que se narran en el presente texto fueron continuos en el discurrir temporal, ese mismo tiempo que, recuperado, es ahora el contenido sustancial de la «memoria», de la misma
Comillas is exceptionally bound to its memory, it must thanks its fame to the same time of artistic splendor, that is basically a time of the past. Memory of the past, then. But such retrospective vision does not have to induce to us to deceits. That past determines and conditions the present positively. It is a good, not an unbearable load.

Of the cultural spaces of Comillas we know almost all necessary, the most relevant. Its origin. Its protagonists. Its facts. The importance of such, its success and its first existance. Also we attended at the time of its later recognition that adjudges the importance of its cultural patrimony, understood like generating collective good of the present phase, characterized by the tourist and popular benefit of that patrimony.

At the present time the villa of Comillas is far away from its original functions, the protagonists who were the cause of its success and fame are absent, reason why what prime it is his value like "space of the memory".

Retrospectively, it is commonly accepted that the "time» of Comillas agrees basically with the three last decades of the nineteen century, or, tailed according to the determining direct protagonists, with the time of the two first titled Marquesses "of Comillas", Antonio Lopez Lopez and his son Claudius Lopez Bru. The successive intervention of both on the native villa supposes a sum of intentions, artistic and architectonic performances, economic investments, really, of the most ambitious project, unique at its moment, generous and, even, visionary, whose tracks are still remained in the image of the villa. All the facts that are narrated in the present text were continuous temporary running, that same time that, recovered, is now the substantial content of the "memory", in the same way that buildings, gardens and landscape, as well as the own villa, are part of the artistic and monumental patrimony in the most 
manera que edificios, jardines y paisaje, así como la propia villa, forman parte del patrimonio artístico y monumental en el más genuino sentido de dicho concepto.

\section{PALABRAS CLAVE}

Comillas. Paisaje cultural. Plan Especial. Marques de Comillas. Modernismo. Joan Martorell. Palacio Sobrellano. Gaudi. El Capricho. Doménech i Montaner. Seminario Pontificio. Cementerio. Parque. Pintoresco. Arquitectura monacal. "Civitas dei». Jerusalem Celeste. genuine sense of this concept.

\section{KEY WORDS}

Comillas. Cultural landscape. Plan Especial. Marques de Comillas. Art Nouveau. Joan Martorell. Sobrellano Palace. Gaudi. El Capricho. Doménech i Montaner. Pontifical Seminary Planing. Cementery. Picturesque landscape. Monastic Architecture. "Civitas dei». Jerusalem Celeste.

\section{EL ESPACIO CULTURAL Y LAS CAUSAS DEL RECONOCIMIENTO}

Comillas conserva y usufructúa un importantísimo legado cultural que hasta hace escasas décadas se mantuvo incólume respecto a su ideación original. Pero como ocurre con el caso de otros enclaves equivalentes, la villa es orgullosa deudora y al tiempo víctima de su propio patrimonio. Salvando diferencias y escalas, recuerda la loca autoinmolación de Venecia bajo el peso de su propia fama: admirada por todos hasta la rendición artística incondicional, en el presente resulta incapaz de soportar los embates de un destino meramente turístico, sus delicadas estructuras urbanas sufren estigmas sin cuento, a lo que, con el inevitable paso del tiempo, se han venido a sumar los efectos adversos de una naturaleza devenida perversa y corrosiva, mutando así en negativo la justificación fundacional originaria de una ciudad asentada sobre una inigualable paraje natural, que en gran medida había condicionado la elección precisa del sitio.

Comillas como paisaje cultural, como villa de un prestigio artístico que no sólo nadie pone en duda, sino que constituye la causa básica de su permanencia como enclave residencial privilegiado, lo es en base a un doble factor interactuante de excepcional importancia: la bella naturaleza del lugar como determinante de la elección y como juicio estético derivado de la observación exterior del enclave urbanizado, también del entorno marítimo, costero y de tierra adentro, y que le atañe hasta allí y desde donde se alcanza a ver Comillas y desde allí desde donde es reconocida como parte de un magnífico panorama decididamente pintoresco.

El territorio de la elección se concreta en un espacio, el de la villa histórica y su periferia próxima, que sería uno más si no hubiera conocido en un interludio temporal relativamente breve, apenas medio siglo, una intensa ocupación, cultural y ar- 
tísticamente excepcional, muy intencionada, de ese espacio, de tal manera que las transformaciones del paisaje de la villa acaecidas en las tres últimas décadas del siglo diecinueve y los primeros años del veinte no sólo modifican sino que determinan el devenir de Comillas hasta la actualidad, cuya memoria cultural, si no exclusivamente, está ligada de manera muy especial a los hechos y características de ese preciso momento de su pasado.

Para narrarlo con propiedad existe bibliografía específica, aunque todavía no completamente satisfactoria, asunto colateral a nuestro interés, pero que le afecta. Por lo que a nuestro punto de vista se refiere, ciframos en el mero dato de la designación de muchos de los edificios y sitios de Comillas como bien cultural, para avalar el reconocimiento oficial de dicho patrimonio.

Aún con todo el bagaje de reconocimiento público y administrativo, que mantiene en pie el viejo prestigio de Comillas como enclave de exquisita y refinada cultura histórico-artística, y dado que los patrimonios de este género corren el riesgo de su dilapidación insensata y contraproducente, a la larga perjudicial para quienes

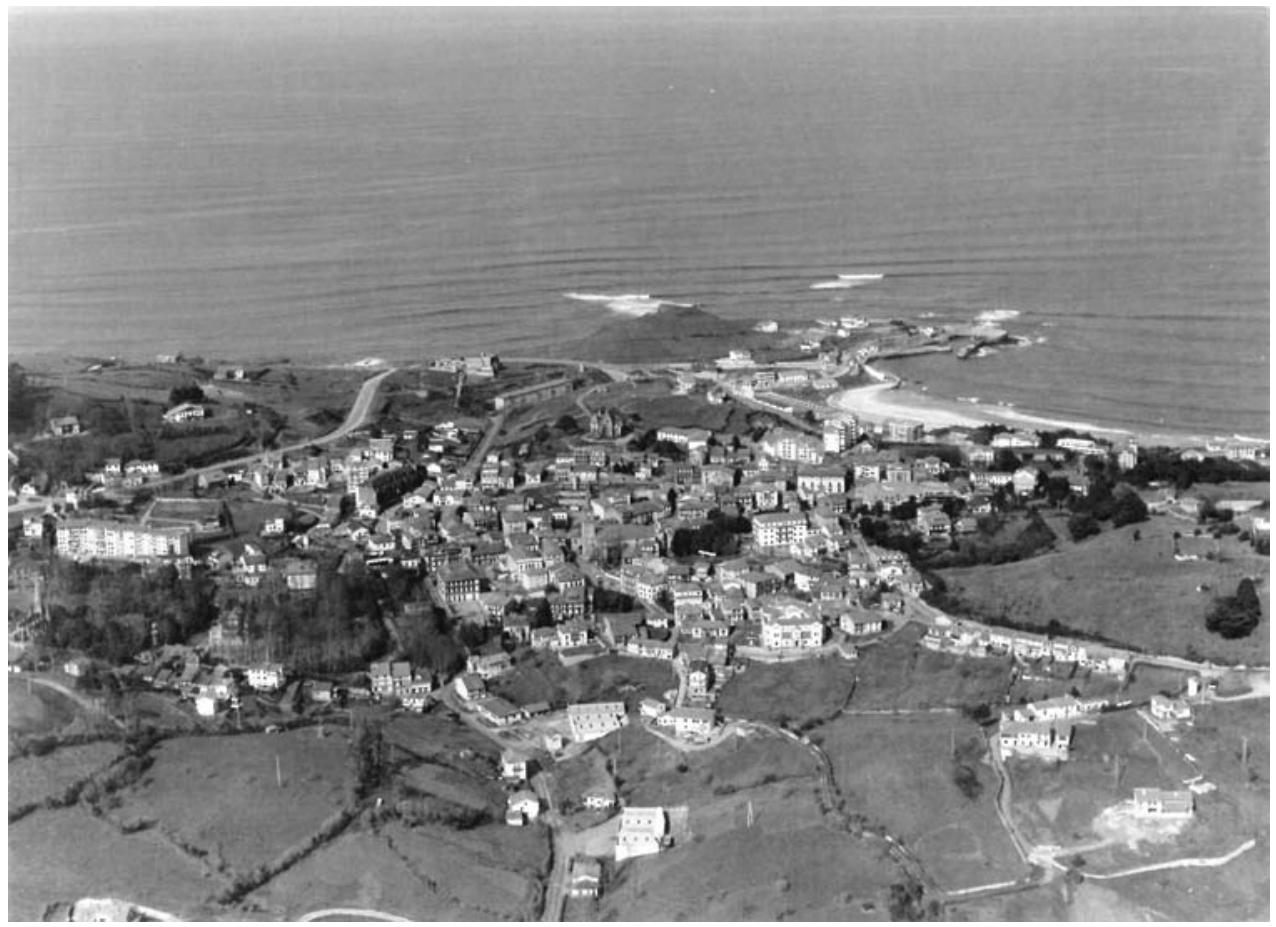

Comillas. El área de la villa antes de su desaforada expansión actual. 
son sus administradores y principales beneficiarios, convendría evitar que las características históricas y la memoria del origen del prestigio cultural de Comillas no se difuminasen o se desdibujasen hasta caer en su patética caricatura, de manera que hubiese que lamentar un futuro, a no tardar mucho, en el que las causas de la fama y del reconocimiento de Comillas quedasen ya sólo en la memoria de sus habitantes y de los estudiosos, por no haber tenido el tiento y la sagacidad de reconocer la idiosincrasia de ese legado y haberlo mantenido según su formulación original.

Comillas, como Venecia, está excepcionalmente ligada a su memoria. Ambas, en sus respectivas medidas, se remiten a un tiempo de esplendor artístico, que es básicamente un tiempo del pasado. Memoria del pasado, pues. Pero tal visión retrospectiva no debe inducirnos a engaños. Ese pasado determina y condiciona positivamente el presente. Es un bien, no una carga insoportable. La sociedad actual justamente valora la cultura y el patrimonio artístico como un bien cifrable en términos económicos. De la misma manera que el suelo urbano alcanza precios superiores en el centro de las grandes urbes, o en las áreas cualificadas y mejor dotadas, ciertos «espacios de la memoria» resultan más valorados y ejercen por ello un más alto poder de incidencia en los procesos económicos en cuanto consiguen mantener incólume su condición de «espacio cultural» y convertirlo en un producto de mercado auténticamente competitivo.

El error, el gravísimo error, del que tantos casos está llena la historia de la modernidad como fracaso, es la unión de la avaricia con el desconocimiento. Avaricia que lleva a considerar el potencial de la memoria del legado del «espacio de la memoria» como un bien en sí mismo, como un filón radioactivo que contaminara con su carga neutrónica positiva todo acontecimiento provocado en su proximidad. Ignorancia y desconocimiento de que lo que venimos denominando «espacio de la memoria» no es un principio energético activo e indefinido, sino que, como el sol, se alimenta de sus propios procesos de combustión que inexorablemente proclaman su extinción. Un espacio cultural pervive alimentándose a sí mismo en base a sus propios elementos constitutivos, y, como el sol, de paso ilumina y da vida a su tiempo, y a un porvenir temporalmente cuantificable. La energía solar sólo la conocemos como resultado de la combustión, pero no podemos entrar en el conocimiento de la materia que al tiempo que se destruye, crea.

En los espacios culturales, sí. Hasta ahí alcanza el valor de la metáfora. De los espacios culturales, de Comillas considerada como tal, sabemos casi todo lo necesario, lo más relevante. Su origen. Sus protagonistas. Sus hechos. La importancia de los mismos, su éxito y su primera extinción. También asistimos al momento de su reconocimiento posterior que le adjudica, como a los santos rápidamente canonizados, el timbre raro, y por ello más advocado, de la cultura pa- 


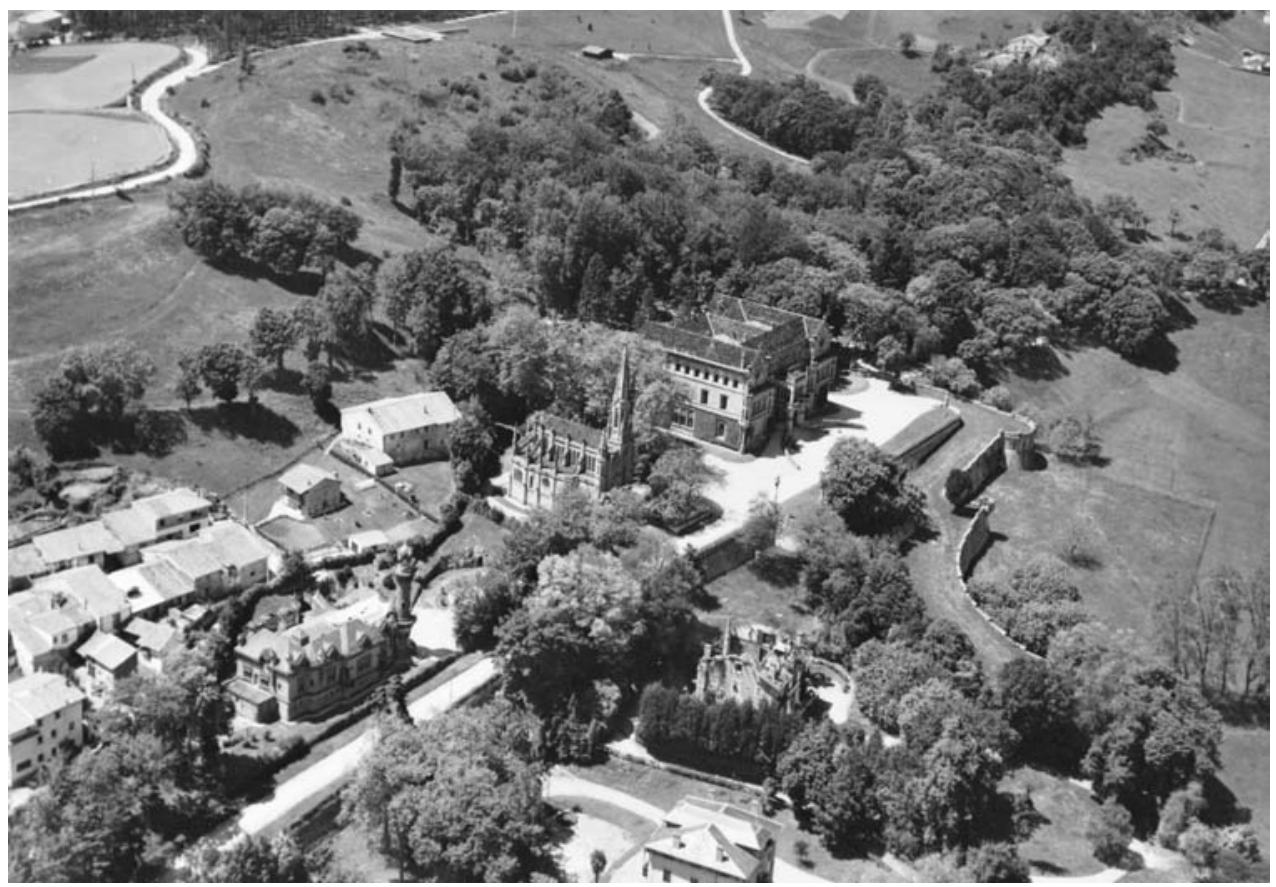

Vista del conjunto del Palacio de Sobrellano (1878-1889), la Capilla-Panteón (1878-1881) y El Capricho (1883-1885)

trimonial como bien colectivo generador de otra fase, o segunda vida, de ese patrimonio alejado ya de sus funciones originales, ausentes también los protagonistas que fueron su causa, pero cubriéndose tan predecible e inexorable destino con los valores nuevos de la cultura auxiliadora, con los valores del rescate del patrimonio como argumento regenerador, y regeneracionista.

El «espacio de la memoria» comienza a desempeñar su benéfica influencia, pero impone sus propias condiciones. No basta invocarlo para que efectúe sus revelaciones. Que son lógicas, racionales, asequibles en sus presupuestos, nunca el resultado de una espúrea sesión de espiritismo improvisado, sino de la comprensión cabal de su genealogía ${ }^{1}$.

1 Comillas es un genuino espacio cultural. La bibliografía, índice implacable con su nivel de impacto, y el asentimiento general no permiten dudarlo en absoluto (vid. Rogelio Pérez Bustamante et alt. "Comillas». Santander 1990. María del Mar Arnús: “Comillas. Preludio de la Modernidad». Guías Electa. Madrid 1999, y parcialmente en Luis Sazatornil Ruiz: «Arquitectura y desarrollo urbano de Cantabria en el siglo XIX», Santander 1996)). Pero lo seguirá siendo en cuanto se sigan dando las concretas y tangibles condiciones - monumentales, espaciales, arquitectónicas, paisajísticas, etc. - que han procurado finalmente dicho doble reconocimiento. 
Retrospectivamente, es comúnmente aceptado que el «tiempo» de Comillas coincide básicamente con las tres últimas décadas del siglo diecinueve, o, contado según los protagonistas directos determinantes, con el tiempo de los dos primeros marqueses titulados «de Comillas», Antonio López López y su hijo Claudio López Bru. La intervención diferenciable entre ambos sobre la villa natal, sobre el solar de la tierra propia, supone una suma de intenciones, de actuaciones artísticas, de inversiones económicas, de un proyecto ambiciosísimo, único en su momento, generoso e, incluso, visionario, cuyas huellas permanecen indelebles en la imagen de la villa, la cual pasa a constituir un ingrediente más del proyecto de transformación y mejora del lugar que en un relativamente breve espacio de tiempo cambia su configuración y se llena de nuevos contenedores artísticos, con simbólicos contenidos, a varias escalas y con distintas intensidades, pero todos continuos en el discurrir temporal, ese mismo tiempo que, recuperado, es ahora el contenido sustancial de la «memoria», de la misma manera que edificios, jardines y paisaje, así como la propia villa, forman parte del patrimonio artístico y monumental en el más amplio sentido de dicho concepto.

\section{LA ARQUITECTURA DE LA VILLA Y LOS ESPACIOS VERDES}

La arquitectura tradicional de la villa, así como edificaciones de nuevo gusto y de cultura cosmopolita se realizan al amparo de su papel como «capital» del verano norteño del marquesado y de la aristocracia afín. En la actualidad ambos dos estratos conviven en la faz de la villa, y se mantienen, pese a todo, los elementos de su identificación, aunque en ocasiones hayan variado sus funciones originales. Son casas, jardines y huertas que junto a los elementos de diseño urbano, plazas, muros, puertas, rincones arbolados, propiedades de particulares realizadas de manera estilística contaminada, en cuanto sus estilos y maneras no concuerdan con evoluciones «vernaculares", sino que vienen directamente importadas con su prestigio cosmopolita contrastado, como también son maestros cosmopolitas sus trazadores, que "depositan» sus proyectos e ideaciones eclécticas variadas sobre los verdes prados de la cornisa comillense, en sus altozanos, entre los riscos altos de su caserío, más tarde en sus aledaños hasta alcanzar los parajes de la ría, siempre con un tono acorde con el impuesto y aceptado por la causa generatriz, el palacio y la actitud del marqués, aunque a un nivel de pretensiones menor, pero consolidando la actitud artística decididamente experimental, sofisticada, relevante y con un afán de trascendencia del promotor e ideador de Comillas como (futuro) espacio cultural, esto es, el primer marqués de la villa, y por causas de variada índole que abocan a la consolidación de la imagen de Comillas como espacio cultural de referencia. 


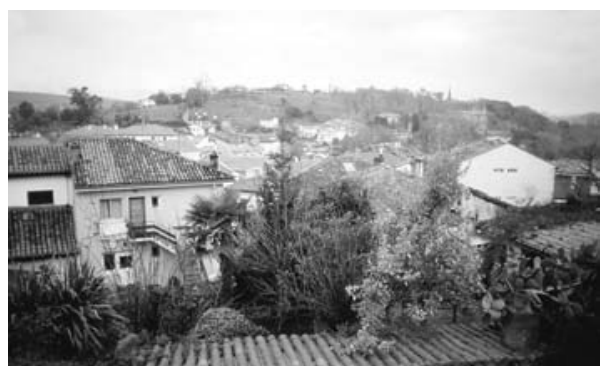

Comillas. Aspecto del casco urbano.

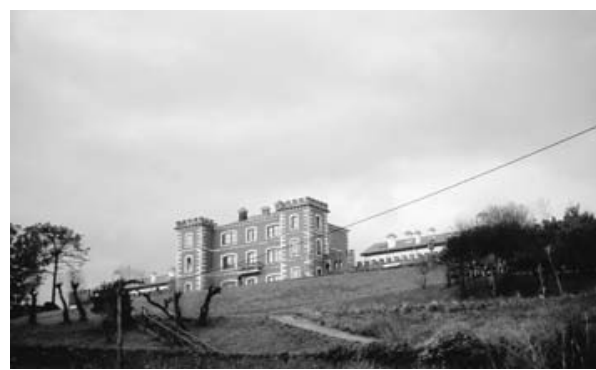

Comillas. Aspecto de la arquitec tura ecléctica residencial.

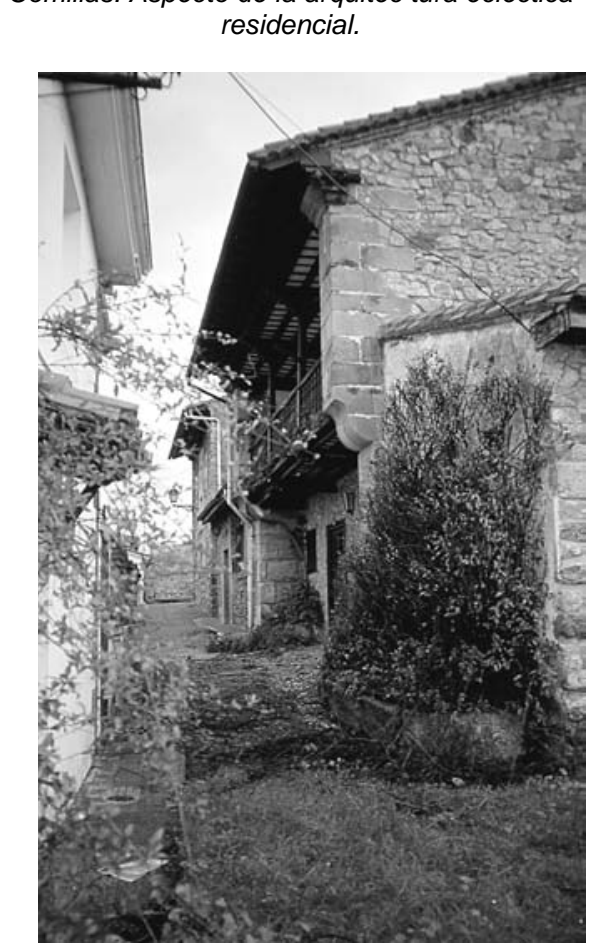

Comillas. Casona tradicional en el casco

Comillas. Casona tradicion
urbano.

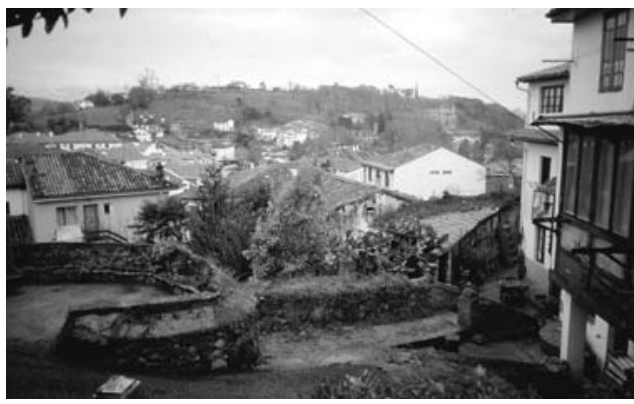

Comillas. Aspecto del casco urbano.

La villa cumple el papel de pasivo protagonista, pero recibiendo directos beneficios al dejarse transformar para pasar a ser la más diferente de todas las de la cornisa cantábrica. Su naturaleza distinta será su ¿inagotable? fortuna futura. La dualidad le procura pintoresquismo vernacular y emancipación cosmopolita. El ideal equilibrado. Regionalismo de viejo cuño y eclecticismo internacionalista. La aristocracia periférica se incrusta en el núcleo del casticismo local. Por ósmosis relajada 
salen ambos reconfortados con el sólido vecindario estacional. Aunque guardando las distancias. Y los estilos. Y las autorías. Unos, dentro del anonimato popular de las formas y materiales consolidados por el beneficio de la experiencia. El eclecticismo de los veraneantes destapa la curiosidad por «lo otro», el gusto por los detalles. El paisaje se concreta en elementos diseñados que perviven en la villa: muros de jardines, tapias, plazuelas, «belvederes» que salvan de manera debidamente aterrazada los niveles de las suaves lomas donde la villa se asienta. Por imitación, o por prestancia, el caso es que la villa se amolda al tiempo de la distinción y ella misma, en su interior o inmediata periferia, trueca corrales y prados por huertas y jardines, refuerza su pintoresquismo y se «amadama» a la manera de los balnearios costeros del momento. Ese bien todavía constituye hoy parte de su capital urbano, pues Comillas no puede anularse o disiparse a sí misma como villa, con sus espacios y arquitectura específica, en aras a que bajo el epígrafe de su nombre resuenen sólo y exclusivamente los contenidos de sus importantísimos monumentos modernos y el paisaje transformado por causa de la presencia de los mismos.

Desde la consideración de su importancia exclusivamente botánica Enrique Loriente catalogó varios parajes de interés en la villa, al margen de los reconocidamente monumentales que suman alrededor de una cuarentena de «sitios botánicos", en muchos de los cuales se dan la suma de otros contenidos además de su condición de oferta de verde en el interior del suelo urbano, pues la imagen y forma de sus muros, puertas, recodos, tratamiento de su posición y adecuación con el exterior, resultan considerandos de un capital que le pertenece ya al común social, procurado por el inicial interés de sus dueños particulares de disfrutar interiormente del beneficio jardinero, hortofortícola o botánico, de las especies adaptadas y cultivadas en tales fincas y terrenos ${ }^{2}$. De manera que una cultura del jardín como elemento espacial de la convivencia urbana se ha dado juntamente con las grandes reservas de verde acotadas a la otra escala añadida, la de los territorios de los monumentos, del palacio, del seminario, del cementerio, tres edificaciones, tres fun-

${ }^{2}$ Enrique Loriente: "Arboles singulares de Cantabria», ed. Tantin, Santander 1992. Citamos siguiendo su recuento: parque del palacio de Sobrellano y colinas adyacentes considerando todo ello como conjunto. Adyacentes a él, la finca de la viuda de Olano, en la Fuente Real; la finca de doña Beatriz de la Torre Trasierra, hoy del conde de Orgaz; la finca del marqués de Lamadrid; la finca de doña Mercedes Satrústegui; la finca de don Claudio Güell de Sentmenat. Los jardines y parque de la Universidad Pontificia de Comillas - monumento histórico-artístico-, y en la misma ladera, la finca de don Antonio Sert; la finca del marqués de Monteflorido; finca La Pradera, de don Santiago García Castellón; finca de doña Elena Pérez Ynguanzo; finca de la marquesa de Retortillo; finca de don Luis Fernández Mellado. Y, además, entre otras más de un prolijo catálogo: finca Prado de San José, en la playa de San Martin; finca de Paulino Moro; finca Santa Lucia, de la familia Carrancejo; finca La Coteruca, de don Manuel Sánchez Movellán, marqués de Movellán; finca El Gato, de doña Ena Weber Duran, viuda de don Federico Pérez y Pérez; finca El Jarón; finca Rovacias; finca de don Lorenzo Correa; finca del hotel Casal de Castro; finca Castrorrubio, con jardines; finca de la familia Ortiz de Zárate; finca de María Paz Movellán; finca Cotalbío; finca Castroalbío; finca de don Nuño Aguirre de Carcer; finca de María Teresa Gutiérrez; finca y jardín Los Hornedo... 
ciones históricamente ligadas desde su condición estrictamente edilicia a su expansión cultural irradiada a un entorno transformado en base a su valoración culta como parque o jardín.

Si nos remitimos a consideraciones estrictamente patrimoniales y de enjuiciamiento arquitectónico, Eduardo Ruiz de la Riva identifica la singularidad monumental de la casa-palacio «La Coteruca» -1870—; la casa "Gerramolino» en La Rabia; la casa del Duque de Almodóvar; la casa del Conde de Sert, del arquitecto Olasagasti; la casa del Marqués de Monteflorido, en realidad una casona trasladada; el conjunto de torre y edificaciones adláteres que constituyen el Golf de Oyambre; la casa «Olano» en La Rabia, del arquitecto J. A. Coderch, de1957, además, por supuesto, de «El Capricho» y el palacio de Sobrellano ${ }^{3}$.

Sin embargo, pese a los esfuerzos de sensibilización acerca de la importancia del conjunto de la villa de Comillas tanto en lo arquitectónico como en lo botánico y paisajístico, tal legado sufre la falta de una justa valoración y en la misma medida en que lo ha sido - hasta protagonizar casi exclusivamente la imagen reconocible del «sitio» de la propia villa en su totalidad - su parte alícuota monumental. Por lo mismo, resulta conveniente y oportuno resaltar el interés y calidad de a construcción del «casco histórico» de la villa, tanto en sus términos topográficos, que contribuyen eficazmente a evidenciar la consideración pintoresca de la implantación del caserío tradicional, como en la relación de ese mismo caserío con los espacios verdes intercalados entre el mismo (en sentido estricto, formando parte intrínseca del mismo), así como también los vínculos formales y compositivos de dichos espacios verdes en relación a las construcciones con las que se unen o las que directamente pertenecen ${ }^{4}$.

3 Eduardo Ruiz de la Riva: «Casa y aldea en Cantabria», Santander 1991.

4 En este sentido podría insinuarse un pequeño ejercicio de organización según el grado de reconocimiento de los espacios verdes de Comillas, siguiendo un somero análisis visual, de lo cual se desprenderían, al menos, los siguientes resultados":

Espacios verdes: grandes jardines

- parque, jardín y colina de Sobrellano

- jardines de la colina del Seminario Pontifico (colina de la Cardosa)

- parque y monumento al marqués de Comillas (formando unidad compositiva y visual con el parque y cementerio histórico, jardín y finca del duque de Almodóvar y futuro parque y cementerio de nueva planta en terrenos costeros colindantes)

Espacios públicos urbanos de pequeña y mediana escala

- parques arbolados de la colina del hotel del Casal; parque arbolado adjunto a la denominada Quinta de Santa Lucia

- espacios conformados en el caserío histórico

- espacios públicos arbolados sin conformación determinada o residuales

Jardines privados

- Casas con jardines singulares

- Casas con huertas agrícolas, huertos arbolados, patios o delanteras someramente ajardinadas. 


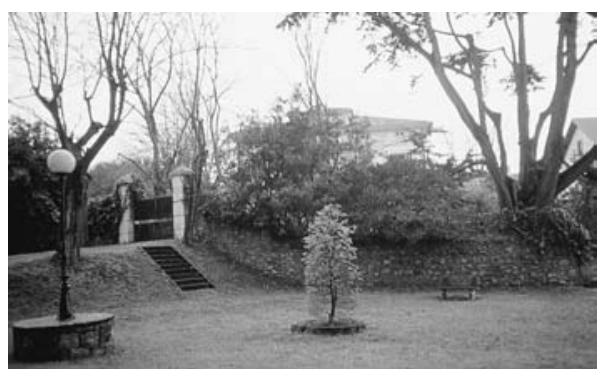

Comillas. Espacios verdes dentro del casco urbano

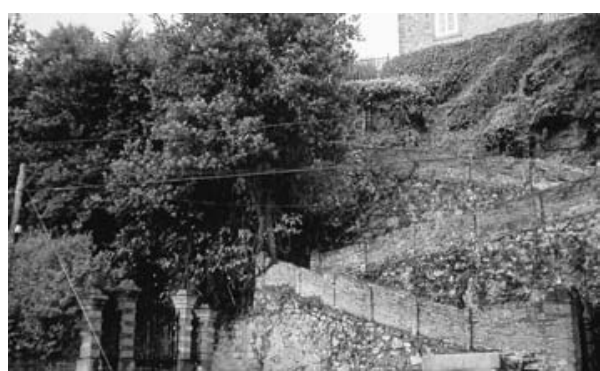

Comillas. Detalles de tratamiento del interior del casco urbano tradicional.

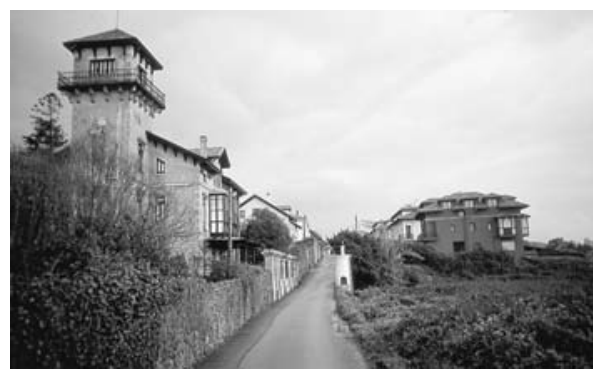

Comillas. Los bordes construidos el casco urbano tradicional.

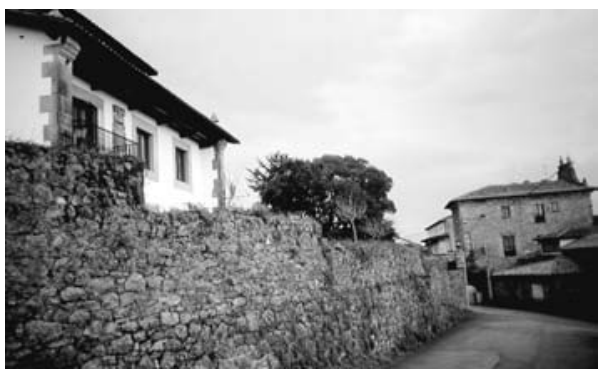

Comillas. Vista parcial del casco urbano tradicional.

El grado de formalización de dichos espacios verdes es, evidentemente, desigual, dado que en ciertos casos se acercan a trazados regulares de jardinería culta, con elementos constructivos reconocibles según dicho ajardinamiento (casa y finca del duque de Almodóvar, casa Gerromolino) en donde se hacen evidentes los aterrazamientos artificiales, las escalinatas de doble tramo, síntomas de parterres de flores y de césped, a otros casos en los que directamente se podría hablar de jardines cuidados sin diseño formal concreto o identificable, pero compuestos con cuidado y armonía (finca «El Gato») o dispuestos para usufructuar la disposición escenográfica de la casa y los puntos de vista (casa "Sert», casa "Benjumea», casa «Coderch» en la Rabia), casas de jardines modernos levemente conformados según principios alusivos a los tradicionales (casa "Los Tilos», casa «Armada»), fincas urbanas con jardín en forma de parque boscoso de pequeña escala e ima-

En este último apartado, evidentemente resultan más fácilmente identificables los pertenecientes al primer epígrafe; nos limitamos a enumerar algunas de las más destacadas o conocidas según esta valoración: Finca «La Coteruca»; Finca del duque de Almodóvar; finca «La Gavota»; finca «Castrorrubio»; casa «Moro»; finca «Santa Lucía»; casa Sert; casa Benjumea; finca «El Gato»; finca "Correa»; finca «Los Tilos»; finca «Armada»; finca «Gerromolino»; finca y parque «Ruiseñada»... 
gen de abandono romántico (finca «Correa», que incluye un atractivo pabellón de biblioteca; finca y parque de «La Gavota»), etc. etc.

Además de ello, se valora como un auténtico bien patrimonial de la villa, como característica personalidad destacada de la misma en lo que a valores espaciales se refiere, la constante presencia de recodos, rincones, aprovechamiento en ocasiones de mínimos resquicios que los vecinos cuidan y preservan con evidente mimo, tanto desde su condición de propietarios particulares (huertos, patios y delanteras de las viviendas) como cuando dichos espacios lo son públicos.

Destacamos así mismo la calidad material y de diseño y construcción de temas aparentemente complementarios de la jardinería, como cierres, puertas, tratamientos de muros, etc., que en esta circunstancia cumplen la doble misión de, en ocasiones, configurar desde su perímetro exterior imágenes urbanas de calles 0 encrucijadas (cierre de la finca «Castrorrubio», acceso a la finca frente a la quinta «Santa Lucía», cierre de la finca»Correa»...)

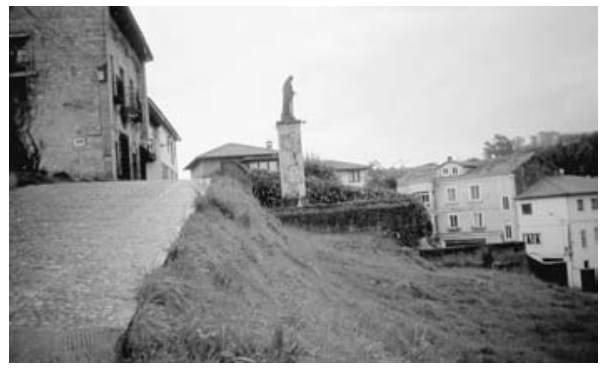

Comillas. Vista parcial del casco urbano tradicional y su relación con los espacios verdes

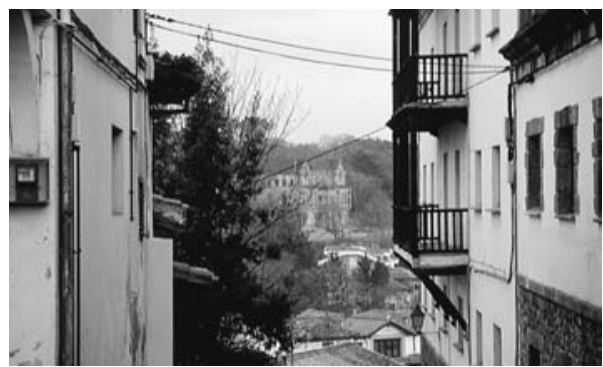

Comillas. Casco urbano tradicional y Palacio de Sobrellano al fondo de la imagen.

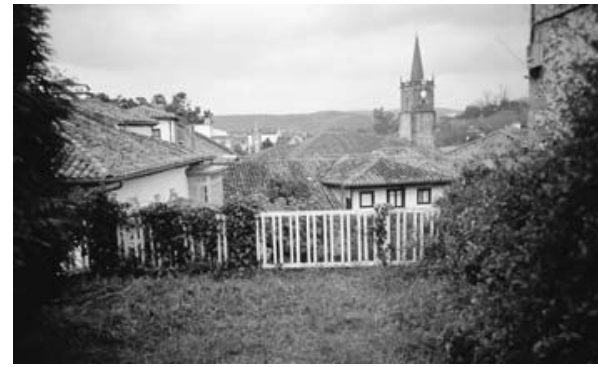

Comillas. Vista parcial del casco urbano tradicional y su relación con los espacios verdes.

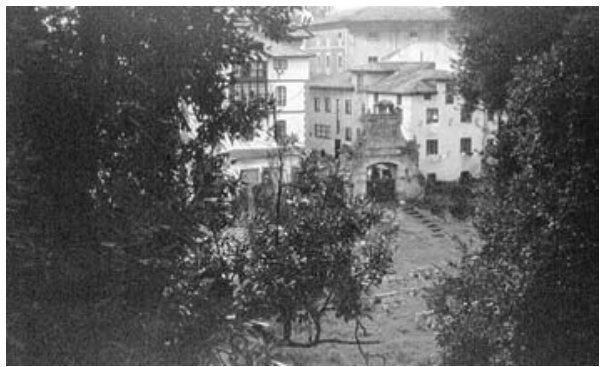

Comillas. Casco urbano tradicional.

(C) UNED. Espacio, Tiempo y Forma Serie VII, H. ${ }^{a}$ del Arte, t. 18-19, 2005-2006 


\section{PALACIO Y PARQUE DE SOBRELLANO}

Cronológicamente la primera obra que emprende el entonces, en 1878, recién nombrado marqués de Comillas Antonio López (1817-1833) es la del palacio. Las obras se inician en 1881 y se concluyen en 1888.

Entendemos que el palacio proyectado por Joan Martorell, al igual que la capilla-panteón (1882) y la casa para Máximo Díaz Quijano, cuñado del marqués, popularmente conocida como «El Capricho», proyectada por Antonio Gaudí y construida entre 1883 y 1885, aunque diferenciables en su potente singularidad, forman entidad unitaria bajo una doble consideración ideológica y espacial, a la que posteriormente se unirá la erección del Seminario, a partir de 1883, concluyéndose las sucesivas ampliaciones de éste en la década de los años cuarenta del siglo veinte.

El palacio, potente mole de veinte metros de altura, se alza como un declarado monumento arquitectónico de Antonio López a su éxito en su tierra natal. Es la cabeza de serie, un extraño invitado estilístico que sobresale y ejerce un imantado poder sobre la historia edilicia de la villa, un efecto que queda recogido en la

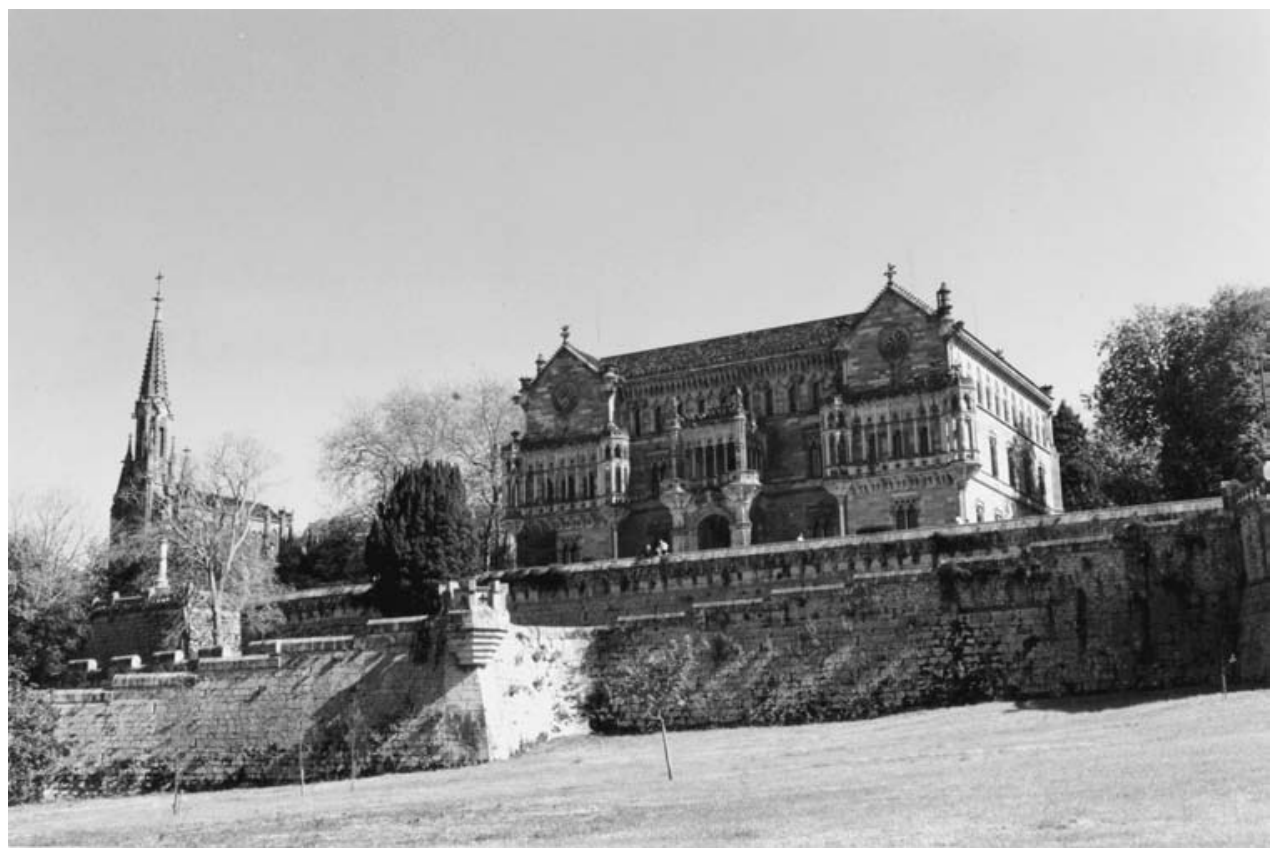

Palacio de Sobrellano (1878-1889) y Capilla-Panteón (1878-1881). 
"Guía» de $1881^{5}$ que lo cita como «futura» casa destacada, unida a las de Patricio Satrústegui, Eusebio Güell, Evaristo Moro, Vicente Carranceja, José García Alvaro, o Fermín Riera con su finca «La Coteruca».

En la ladera norte de la colina, creando su propia plataforma de aposentamiento, como venido de lejanas tierras y referencias estilísticas (neogótico inglés, láminas a lo Viollet le Duc, carcasa gélida de otro «Pierrefonds» pasado por el cedazo de un «palazzo» de canal veneciano...), las referencias cultas válidas son manufacturadas por el autor de la idea, el muy culto arquitecto catalán Joan Martorell, ajeno hasta entonces, y después, a Comillas como destino de sus vuelos y desvelos arquitectónicos. En este sentido, el debate arquitectónico comillense es un ectoplasma del de Barcelona, y allí sí es más comprensible y fáctico enfrentarse al academicismo del arquitecto y director de la Escuela de Arquitectura de Barcelona, Elías Rogent, la otra autoridad de referencia. En la «Nota necrológica» aparecida en la revista «Arquitectura y Construcción» de noviembre de 1906, el también arquitecto Manuel Vega y March le define a Martorell como un innovador, como el fundador de la moderna arquitectura de Cataluña, como el más firme e inspirado de los arquitectos, digno de figurar en la vanguardia del renacimiento y apogeo del arte catalán del siglo diecinueve.

Moderno, pero sin alcanzar el entonces debatido concepto artístico modernista. Maestro de excelentes discípulos, que le prolongan ahora también en Comillas: Antonio Gaudí, Cristóbal Cascante, Lluis Doménech i Montaner.

Parte del debate cultural que en Barcelona resulta apasionado y verosímil, lo vemos transfigurado en Comillas por el deseo de un ennoblecido marqués inmensamente rico que lleva con él a su tierra natal no sólo la «locura» de construir un fantástico y ajeno palacio, sino de levantar en la villa, por su causa y como manifestación de su arrollador éxito económico y comercial, un auténtico «Xanadú», un centro social de verano, y repercutir entre sus paisanos inmediatos parte de sus beneficios debidamente edulcorados con la capa fina de la cultura artística.

De esta manera, al tiempo de ser nombrado marqués, construye la imagen nueva de Comillas desde la perspectiva cosmopolita de Barcelona, su verdadero centro de operaciones mercantiles, la génesis de su poder económico. Como ha narrado con discurso irrefutable Juan José Lahuerta ${ }^{6}$, Antonio López, con un afán transparente de legitimación social, se empeña en implicarse con los nombres emergentes comprometidos de diversas maneras con la cultura catalana, y así resulta ser el financiador de la publicación del poema épico de Jacin Verdaguer “L'Atlantida. L'Espanya Naixent», con el que éste había obtenido el premio extra-

5 «Comillas. Apuntes históricos». Imp. y Litografía J. M. Martínez.

6 Juan José Lahuerta: “Antonio Gaudí. Arquitectura, ideología y política». Electa. Madrid 1993. 
ordinario de los «Jocs Florals» de 1877, o, también, a un nivel arquitectónico urbano más evidente, instala su domicilio en un representativo palacio dieciochesco de la parte alta de las Ramblas barcelonesas, el palacio de Moja.

Pero la perspectiva era muy otra al «ocupar» el territorio de su tierra natal, el suelo del hogar, origen de sí mismo, y que comprará acaparándolo hasta cambiar la faz territorial, como bien muestra el plano de Cristóbal Cascante, de 1885. Así nos lo describe críticamente Lahuerta: «Era el, el marqués de Comillas, quien prestaba el lugar y «tejía» las relaciones: se trata, de nuevo, de una acción aparentemente conciliadora, en realidad agresiva (...). Si en Barcelona Antonio López había podido comprar el tiempo, la riqueza y el prestigio del palacio Moja, en Comillas descubrió y valoró inmediatamente las ventajas sociales y políticas que podía obtener de la utilización de las formas artísticas modernas»? 7 .

Al reclamar el trabajo creativo e innovador de Martorell, entonces en el centro de la actividad cultural y arquitectónica barcelonesa, aunque no resultando siempre un neto triunfador (sí lo fue en la construcción imponente de las Salesas, pero fue rechazado con su propuesta presentada al concurso de la fachada de la catedral de Barcelona, en 1882), el marqués llevaba incorporado con su nombre la mejor oferta posible de prestigio cultural combativo, sin escatimar por ello costos, porque ahora el que había salido como paria vecino a la aventura americana volvía como mucho más que cualquier otro «indiano» y podía permitirse comprarlo todo.

Se lleva, pues, a Comillas, «novísimas tendencias que suplen la falta de tiempo acumulado en Comilllas " ${ }^{8}$, tradición restaurada por parte de éstos arquitectos modernos que desembarcan en la discreta villa para elucubrar allí, mediante la arquitectura y en aquel paisaje, una historia inventada, convertida en patrimonio, con la finalidad dirigida de celebrar el poder de su aristocrático promotor, a quien todo se debía y para quien todo iba destinado.

Pero no sólo el palacio, pues la propia familia real refrendará con su pronta presencia, a partir de 1881 , el reconocimiento del éxito. Carmen Güell ${ }^{9}$ nos evoca el eco de la primera estancia de Alfonso XII en Comillas: «El conde de Sepúlveda, gentilhombre de la corte, describió así la impresión causada: «Los ministros, los funcionarios, todos los que acompañan a la familia real dicen lo mismo, todos cantan al unísono la apología de Comillas; todos dicen que ésta es una página encantada del libro misterioso de la Montaña; que allí en aquel parque, en aquellos paseos entre árboles, sobre aquella playa abierta a la brisa del noroeste, se han re-

\footnotetext{
7 Juan José Lahuerta, op. cit., pg. 30.

8 Juan José Lahuerta, op. cit., pg. 34.

9 Carmen Güell: “Gaudí y el conde Güell. El artista y el mecenas». Edit. Martínez Roca. Barcelona 2001, pg. 89.
} 


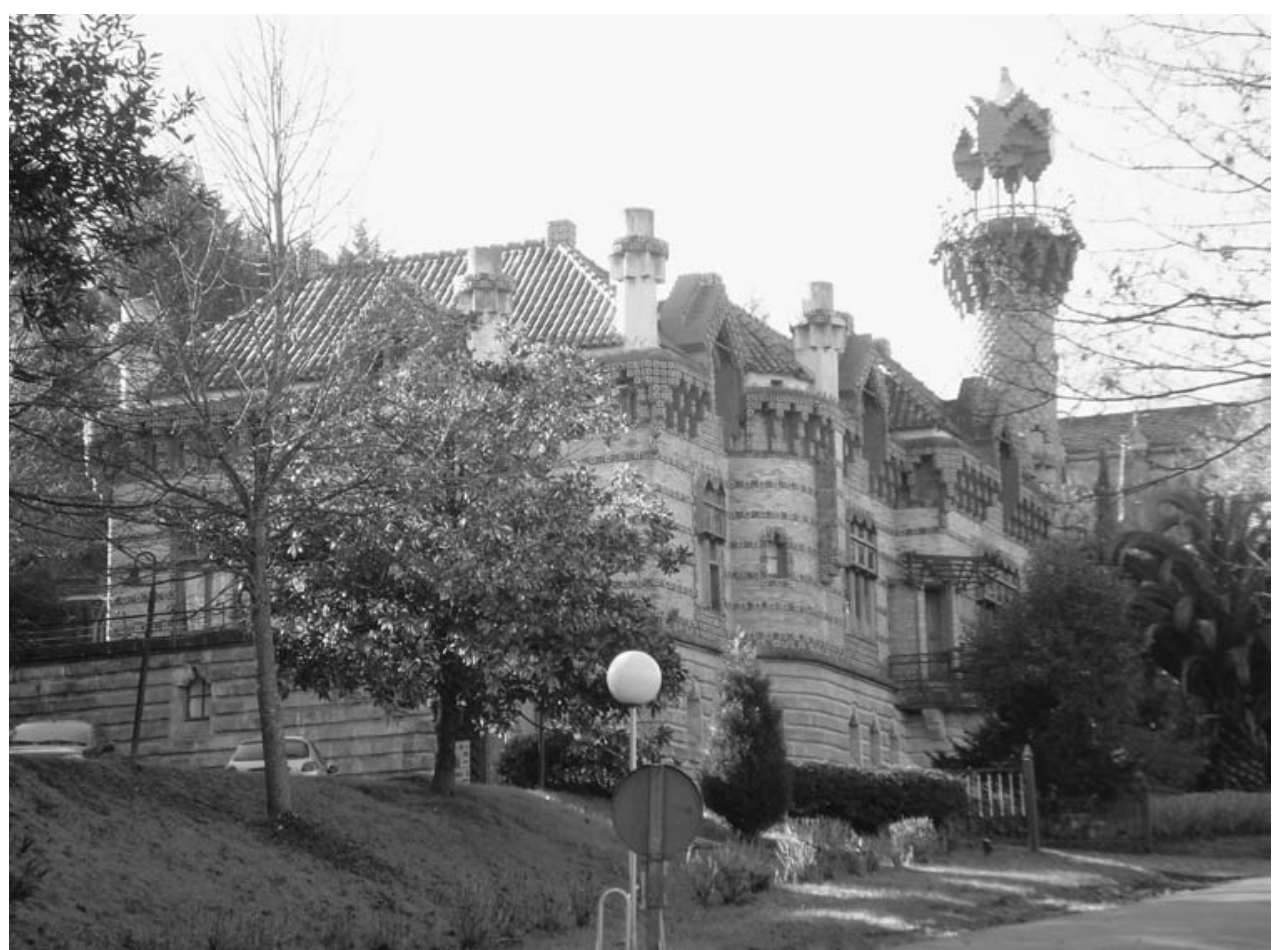

A. Gaudí. El Capricho (1883-1885).

presentado escenas de «las mil y una noches» con príncipes de carne y hueso y magos reales. Pero quienes confirman tales juicios son los mismos soberanos».

Palacio, capilla-panteón, «Capricho»..., y, además todo un parque que se irá ampliando y completando en los años sucesivos hasta alcanzar una dimensión que le hace perderse en los confines del territorio visible, como un mar de verde equivalente al mar que se avistaba desde la torre de «El Capricho». Un parque diseñado pormenorizadamente en las inmediaciones de las arquitecturas a base de elementos de la tradición culta de jardines: ninfeos, parterres de césped, terrazas, rampas, puntos de observación..., que en la proximidad circundante se asimilaba al género característicamente inglés, el paisajista, y en los extremos confines de la propiedad, en las cuestas de las colinas, se convertían en dispersos bosquetes de pinares a la par que se iban integrando en el sistema agrario del territorio campesino alejado, pero visualmente incorporable en tanto que pintoresca composición intencionada desde el punto de vista de observación centralizada, esto es, desde el palacio y sus terrazas. 
Se atribuye al segundo marqués, Claudio López Bru, la extensión de la propiedad y la conversión decidida del territorio adyacente en parque «a la inglesa». Su formación en Inglaterra y la admiración declarada por el marqués hacia la cultura insular apoyan la interpretación del parque en términos de la referida tradición paisajística inglesa.

Joan Bassegoda no se detiene todo lo que desearíamos sobre el asunto que ahora nos ocupa, limitándose a catalogarlo como «parque romántico»: «el jardín del palacio se extendía por una amplia superficie con ondulaciones pendientes en las que crecían grandes árboles, como pinos, cedros y castaños de Indias ${ }^{10}$. Manuel Gómez Anuarbe ${ }^{11}$, en su afán de destacar el valor de lo simbólico y esotérico, rescata interesantes aspectos ocultos, tapados y olvidados, en realidad desdeñados, del trazado del parque, todos pertenecientes a la tradición característicamente anglosajona, consistente en instalar en la aparente irregular disposición del jardín elementos de la tradición culta de este tipo de arquitecturas: grutas, ninfeos, ruinas, templos, kioskos, esculturas, etc., que animaban los serpeteantes paseos, constituían focos fragmentarios del recorrido, componían escenas yuxtapuestas según un orden intencionado pero parcialmente oculto, o, finalmente servían como focos de composición perspectiva para ser vistos en su estratégica posición desde posiciones encajadas en esta calculada geometría irregular paisajística, caso del desaparecido templete clásico en lo alto de la colina próxima.

Experiencias todas arraigadas ahora en Comillas por decisión del segundo y muy anglófilo marqués, perfectamente entendibles dentro de la tradición cultural del jardín irregular inglés, cuyas primeras versiones se habían consolidado ya antes de la primera mitad de la centuria dieciochesca.

\section{EL PARQUE PROYECTADO COMO JARDIN IRREGULAR}

La terraza, los muros de contención, la vía transversal de acceso, el palacio, el ninfeo, los parterres de césped en forma de herradura que bordean a «El Capricho", que, en términos de J. Bassegoda insisten en el concepto difuso de jardinería romántica: «El Capricho muestra un proyecto cuidado, una buena combinación de jardinería paisajística y romántica con una arquitectura jardinera que armoniza con la casa, que así queda perfectamente inscrita en su entorno» ${ }^{12}$.

10 Joan Bassegoda: «Los jardines de Gaudí». Ediciones U.P.C., Barcelona 2001, pg. 23.

11 Manuel Gómez Anuarbe: «Masonería y santidad. Los caprichos de Gaudí en los jardines de Comillas», Torrelavega 2002.

12 Joan Bassegoda, op. cit. pag. 24. 
Al menos en los elementos citados la idea convencional permite «reconocer» la construcción de un jardín, porque la presencia de los mismos lo vienen a significar, pertenecen y remiten a un culto mundo secular de experiencias de jardines. Regulares. Trazados con la condición de su capacidad de modificar el lugar de la intervención mediante los recursos y el arte que se plasma en ejes, terrazas, parterres, agua, fuentes, ninfeos, lagos, canales, grutas, kioskos, vegetación de bajo y alto porte, y el añadido complementario de esculturas simbólicas o alegóricas.

A muy pequeña escala todo esto había en torno a la «tríada monumental» de la loma y ladera de Sobrellano. Introducidos como recursos convenientes, presti-

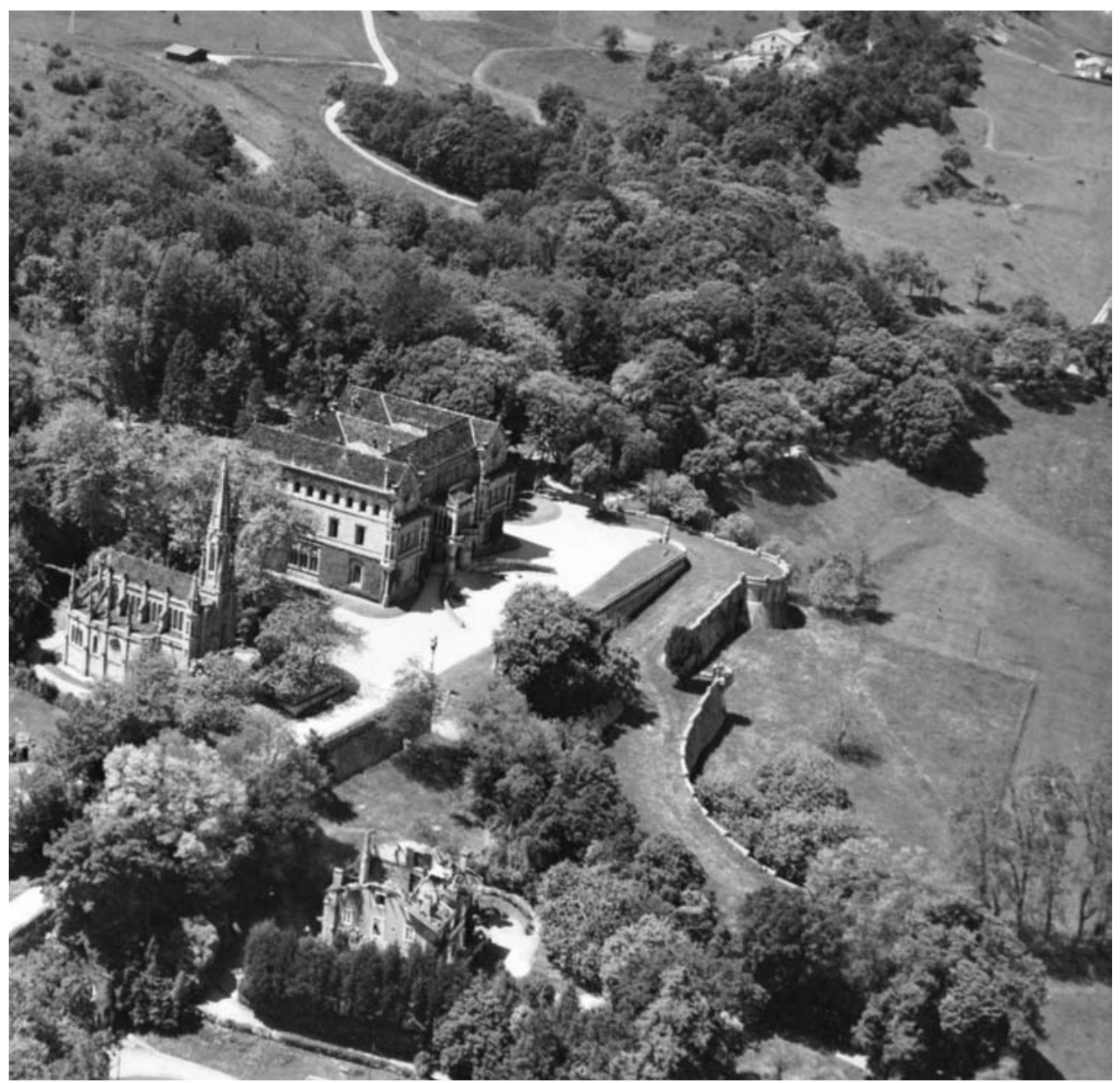

Parque del Palacio de Sobrellano (1878-1889) y Capilla Panteón (1878-1881). 
giando con su haber y su estar el lugar rural del paisaje previo anterior. Restos de una geometría regular modificadora del trazado natural, por sí mismo tendente al (bello) desorden de lo irregular y asilvestrado. No connotado con el arte del jardín regular cortesano.

Pero al paisaje de Comillas se suman dos argumentos que, juntos, resultan axiomas prácticamente irrefutables. Por un lado, sus propias condiciones «naturales»: suaves lomas de valles, rías costeras, arquitectura rural adaptada empíricamente a las condiciones y materiales del lugar. Verdes campiñas cercadas por los bajos muros vegetales y asentamientos de pequeños núcleos rurales junto a edificaciones dispersas que pueblan el territorio. Base preparada por sus características dadas para adaptarse, como otros lugares de la cornisa cantábrica, a un modelo no menos culto de intervención, pero sí menos evidente en el resultado de sus apariencias: el del jardín irregular a la inglesa.

Delimitado el territorio de la propiedad, el jardín irregular pintoresco y/o paisajístico resulta alternativa moderna y ostensiblemente más respetuosa con las leyes físicas del lugar en el que se interviene. La geometría de la irregularidad se subsume y se camufla en las curvas ondulaciones del terreno natural, interviene de manera queda para mejorar, sin apenas notarse, lo existente. Pero posee sus reglas igualmente, las de una ciencia precisa y sutil para leer el genio del lugar y congeniar con él, sin torcer con simetrías y ortogonalidades las características físicas del sitio tal como se encontró, pues la naturaleza por sí misma desconoce las teóricas ventajas del ángulo recto.

El compositor de escenarios naturales recurre a sistemas pictóricos para apoyar las certezas de su cirugía paisajística reparadora, y siempre su materia primordial la extrae de la que se le ofrece espontáneamente, sin apenas esfuerzos o forzadas búsquedas: césped, árboles, arbustos, corrientes de agua, y la lectura atenta de la composición accidental del lugar, tal y como ya había recomendado el poeta Alexander Pope a Lord Burlington en carta escrita hacia 1730:

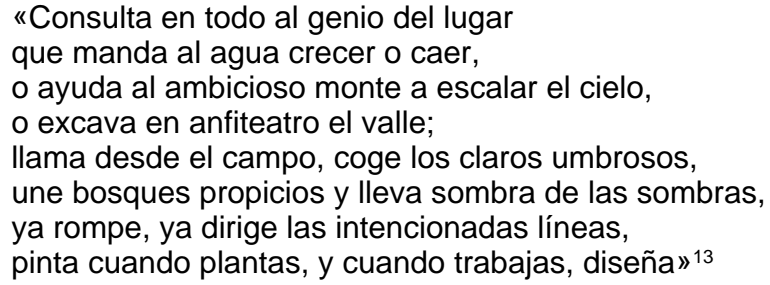

13 Reproducida por R. Middleton y D. Watkin en «Arquitectura Moderna». Aguilar, Madrid 1989, pag. 38. 


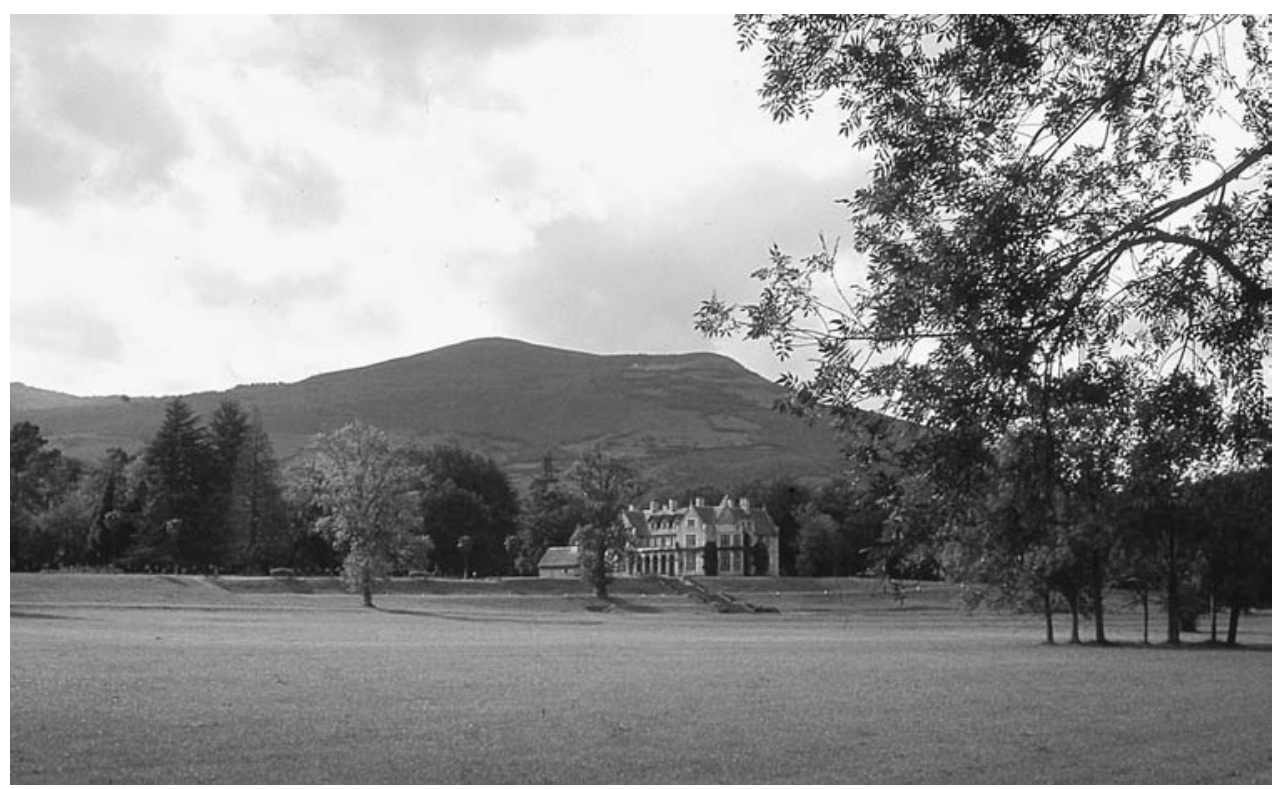

Las Fraguas (Cantabria). Palacio de los Hornillos (finales del siglo XIX).

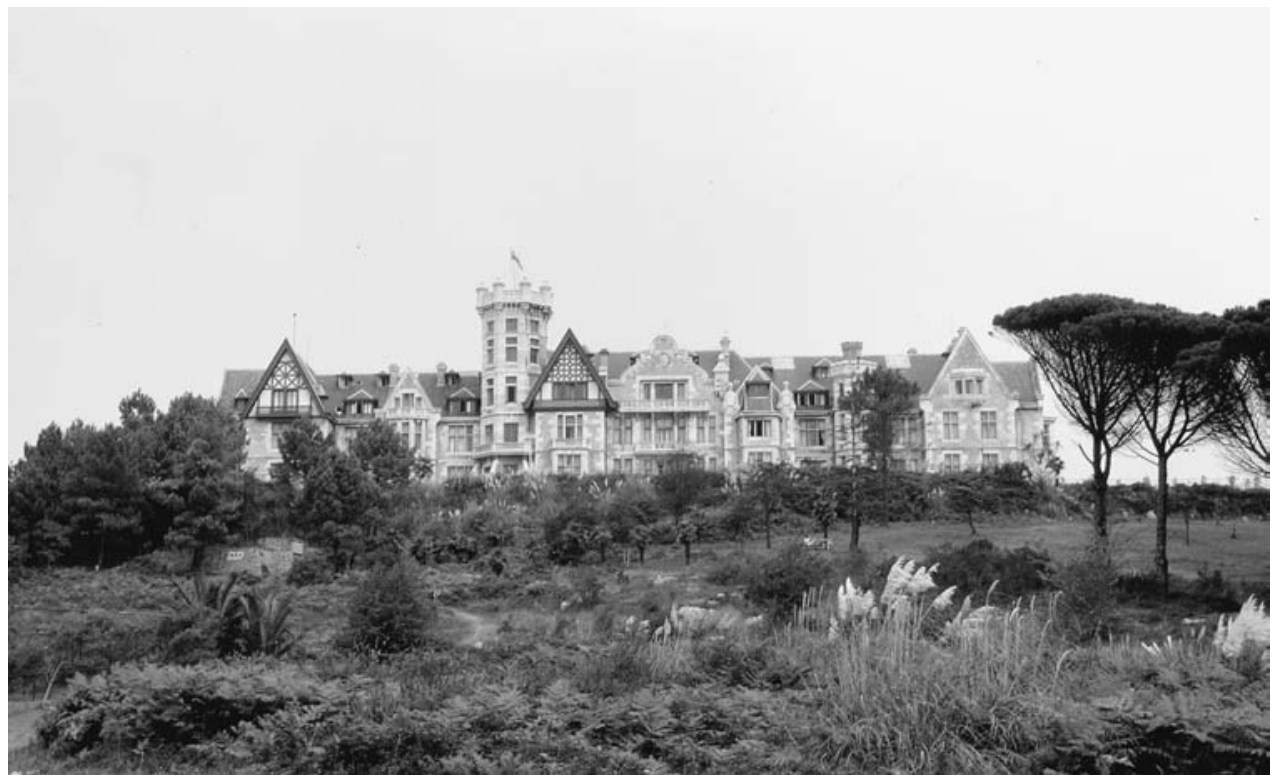

Santander. Palacio de La Magdalena (1908). 
Emergiendo entre las masas de árboles dispuestas a su alrededor, hay fotos antiguas del palacio de Sobrellano y de la aguja de la capilla-panteón que transportan a experiencias de la cultura anglosajona del paisaje pintoresco. Su filiación no puede ser más próxima. Junto con el caso del palacio de Los Hornillos en Las Fraguas de Iguña, y el palacio de La Magdalena en Santander, constituyen la expresión del triunfo aceptado y rendido de la cultura arquitectónica y paisajística inglesa en Cantabria.

En Comillas el palacio se alza en la colina sobre su plataforma y en un interludio de vacío que le oferta la espesura del bosque inmediato que le rodea y le abarca, expandiéndose en sus inmediaciones como parque, como mancha pictórica que se dilata y diluye con perfil adaptado a la pendiente de la colina, hasta alcanzar su loma, para luego continuar por dicha cresta como paseo longitudinal desde el cual poder contemplar cómo la propiedad se confunde visualmente con todo el territorio.

En el plano de Cascante de 1885 hemos comentado el asunto desde una estricta pero elocuente lectura catastral, dado que en él se observa cómo la propiedad del parque, para hacer posible su idea, va «borrando» la parcelación de las pe-

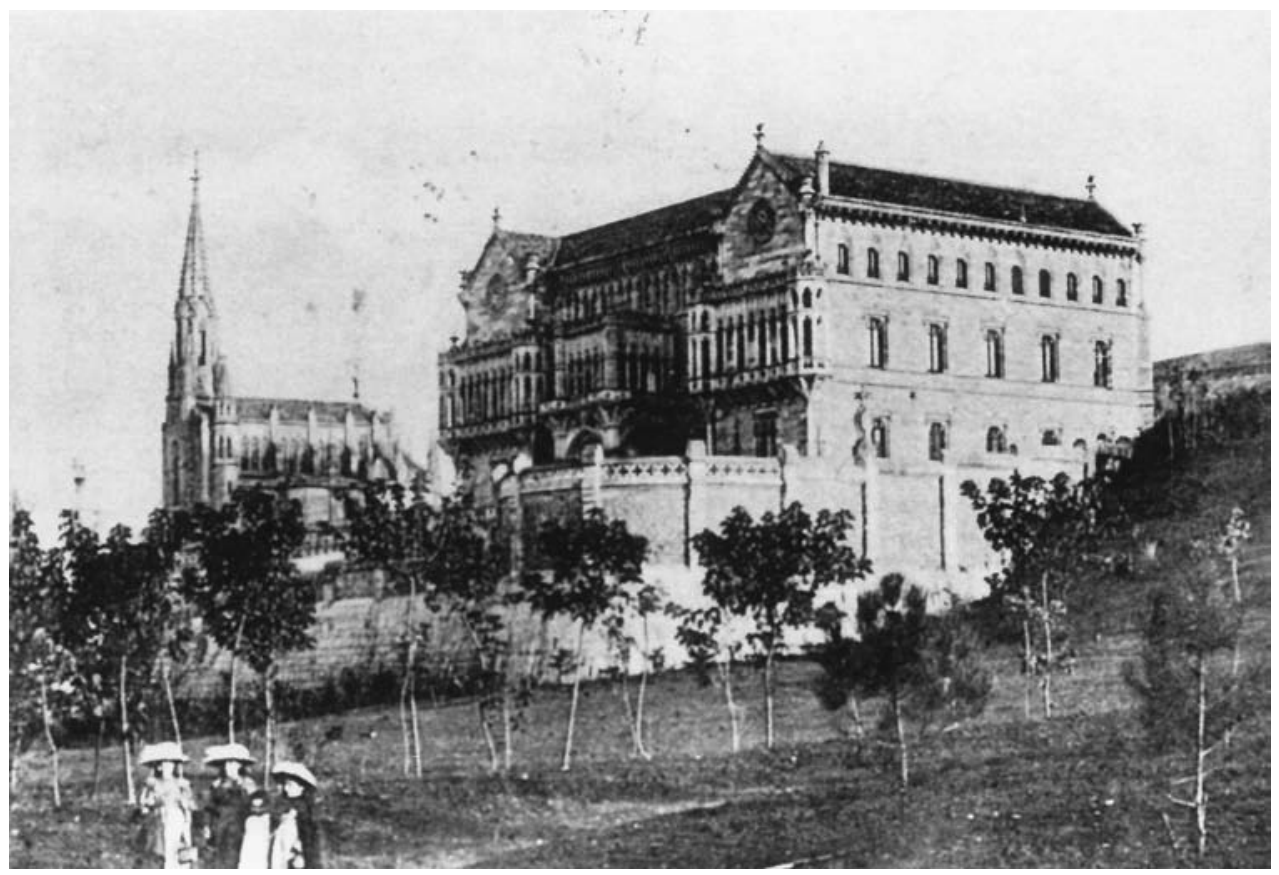

Comillas. Foto de época del Palacio de Sobrellano (1878-1889) y Capilla Panteón (1878-1881). 
queñas propiedades vecinas, de este sistema local de «enclosures», para devenir transfigurado, gracias a la amplitud, en jardín irregular compuesto a la manera «naturalista» inglesa, donde el arte del jardinero básicamente consiste en mejorar las «imperfecciones» del lugar con arte apenas notorio y conseguir que éste resulte a ojos vista el más encantador paraje «natural» posible.

Para no renunciar a la condición de paisaje construido y connotado, se introducen citas puntuales en el mismo, de naturaleza por tanto completamente «artificial», esto es, figuras de la tradición edilicia convencional que, dispuestas con visos de aleatoriedad, responden, sin embargo, a intencionadas localizaciones controladas pictórica y perspectivamente con el fin de ser vistas como parte determinante del recorrido "cultural» a través de un paisaje «natural» construido.

En el parque de Comillas de Sobrellano quedan las huellas rescatables de varias de estas fábricas, incorporadas como fragmentos a lo largo del recorrido por el mismo, dispuestas escenográficamente según puntos de vista que reproducen las intenciones de un pintor de paisaje, elaborando su obra a escala tridimensional. Es el caso del lamentablemente desaparecido templete clásico en lo alto de la colina trasera del palacio, que nos recuerda a pequeña escala la disposición del de Vanbrugh y Hawksmoor en Castle Howard, esto es, citas singulares de cultura clásica depositadas en el paisaje con sensibilidad de pintor y actitud de una sociedad decidida a cualificar el territorio incontaminado de sus ancestros con un rasgo eficaz que lo impregne y lo vacune y lo insufle de los anticuerpos que, al tiempo que lo señalan, lo reactivan y ayudan a salvaguardarse.

En el parque entorno, que idealmente se extiende y pretende ir ocupando todo el territorio, al menos según la metáfora visual aludida, se van incorporando de manera oportunamente accidental los signos de su introducción en el ámbito del paisaje culto que se reconoce como tal: hitos, cruces coronadas de esferas, columnas conmemorativas, cascadas artificiales, arcos de piedra en el camino, columnas romanas auténticas traídas de Julióbriga, canales, templetes, kioskos, grutas artificiales..., todos ellos, y otros varios, habituales «mementos» artísticos en los jardines pintorescos ingleses, lugar de experiencias arquitectónicas diversas, fomento de reflexiones en el ánimo del paseante que por medio de dichos signos tiene la oportunidad de dar rienda a la imaginación poética, retrospectiva, de ensimismarse con la ayuda evocadora de las citas cultas dispersas en el jardín, para transitar sin solución de continuidad al puro placer de la contemplación evocadora, desprendido el espíritu de toda cuita, de todo signo, de toda atadura.

En el recorrido por el jardín, parque y paisaje de Sobrellano, desde el centro simbólico, que no geométrico, desde la arquitectura del palacio, se dan los tres niveles resumidos: jardín con tratamiento de leve regularización, parque con disposición de masas verdes y de arquitecturas emplazadas intencionadamente en el 
recorrido para señalar y connotar con su interposición al parque como lugar de contenidos cultos y artísticos, que Manuel Gómez Anuarbe lleva hasta niveles de interpretación esotérica en su libro citado.

La amplitud, la extensión, el «embargar» de naturaleza dirigida y compuesta el solar de la propiedad por parte del segundo marqués resulta coherente con el deseo de la construcción de un paisaje según las reglas establecidas por el tipo de jardín irregular, aunque sus resultados aparezcan menos presentes que en la opción antitética del jardín regular de la tradición clasicista italofrancesa. Y menos aún en el estado de descuido e ignorancia en el que el parque de Sobrellano se haya actualmente, en contra, como venimos diciendo, de las cultivadas pretensiones de sus trazados históricos, que debieran ser restituidos a su plenitud original, con toda su extensión, incluyendo la reincorporación de los elementos desaparecidos.

\section{LA UNIVERSIDAD PONTIFICIA DE COMILLAS, O LA CONSTRUCCION DE LA COLINA DE «LA CARDOSA»COMO «CIVITAS DEI»}

Frente a la colina del palacio donde el marquesado de Comillas asienta su genealogía y la llena de contenidos profundamente mundanos, fomenta al tiempo la construcción de un bastión de fe y de mensajes escritos a lo divino.

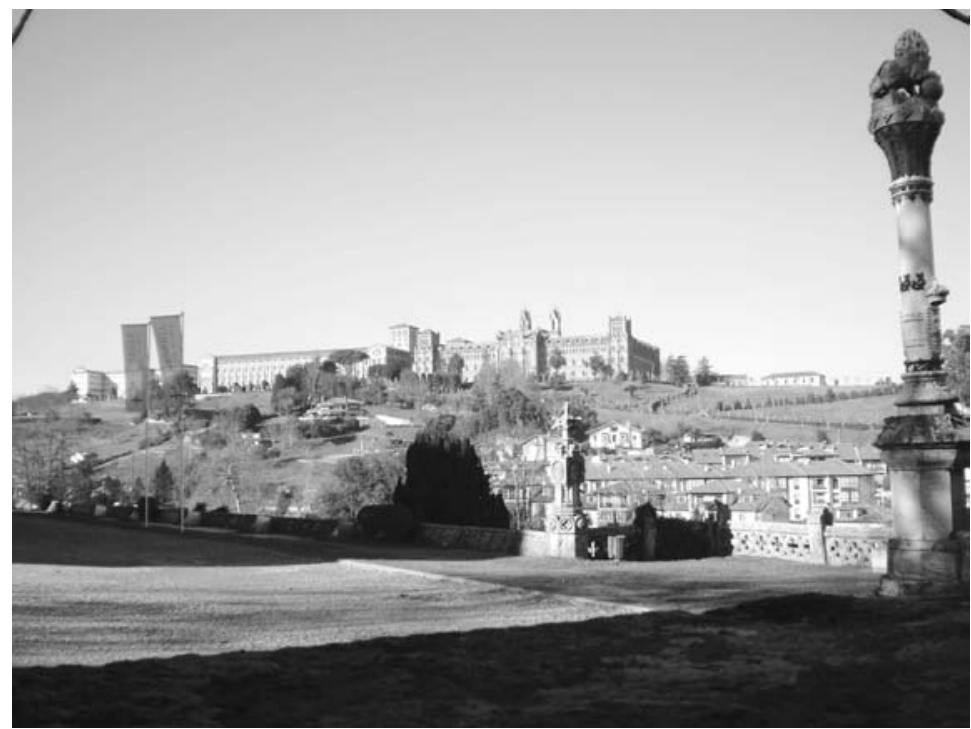

Comillas. Vista de la colina con los tres edificios del Seminario Pontificio (1889; 1912; 1942). 


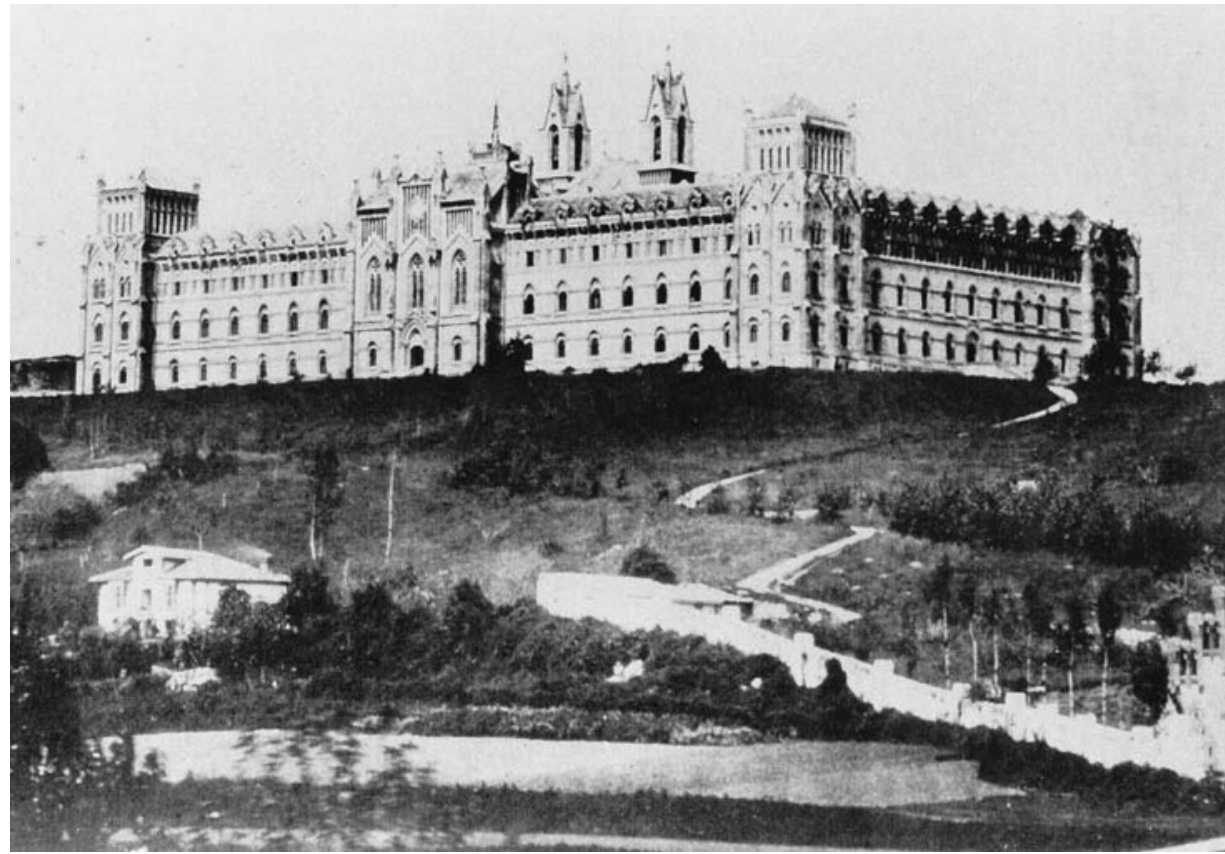

Seminario Pontificio según la ideación original (1889) de J. Martorell, C. Cascante y LL. Doménech i Montaner.

Desde 1883 el segundo marqués, Claudio López, reparte sus esfuerzos y diversifica su economía inversora depositando en la loma frontera grandes esperanzas y no pocas ínfulas artísticas, a las que responde el mismo arquitecto del palacio, Joan Martorell, secundado por Cristóbal Cascante, verdadero artífice a pie de obra. A partir de 1889 interviene Lluis Doménech i Montaner en aspectos puntuales del interior del Seminario, así como en el diseño de la portalada de acceso. Camilo María $\mathrm{Abad}^{14}$ confirma el papel destacado de Cristóbal Cascante y adjudica a Doménech i Montaner las reformas, a partir de la referida fecha de 1889, de la escalera principal, vestíbulo, artesonado de la biblioteca, decoración del salón de actos, así como la factura de la puerta monumental de entrada, y también la de la iglesia.

En 1889 se inaugura la imponente masa gótico-mudéjar del Seminario, vasto rectángulo partido en dos por el cuerpo-crujía en donde se ubica la iglesia, manifestada en altura por sendas torres que sobresalen por encima de la silueta general del conjunto. En 1912 se inaugura a su vez el edificio anexo del Seminario Menor,

14 Camilo María Abad: «El Seminario Pontificio de Comillas. 1881-1925», Madrid 1928. 


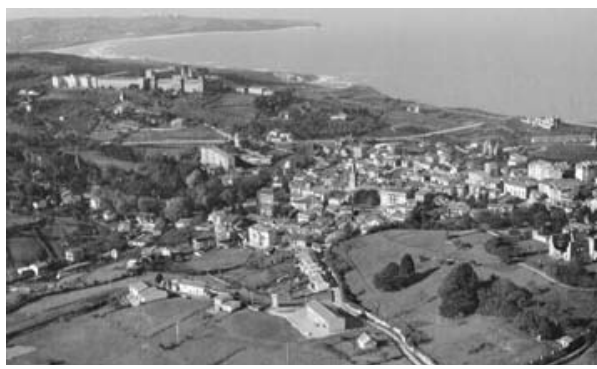

Comillas. Vista aérea, y sobre la colina los tres edificios del Seminario Pontificio

(1889; 1912; 1942).

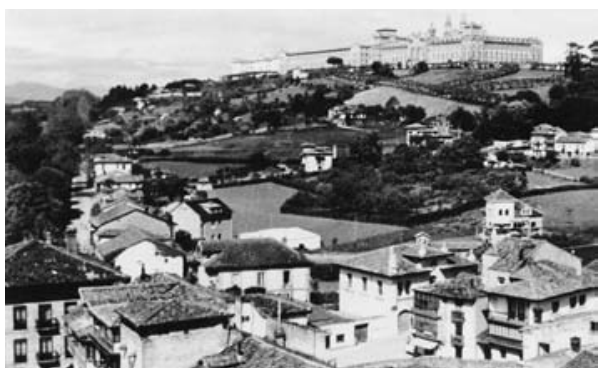

Comillas. Foto histórica del casco urbano tradicional y al fondo el Seminario Pontificio.

obra del arquitecto bilbaíno José Maria Basterra, financiado a expensas de la benefactora cubana Carmen Zoraya, y en 1942, en plena posguerra, se inician las obras del tercer edificio, el llamado Colegio Máximo de Estudiantes, gran colegio mayor hispanoamericano, "civitas supra montem posita», frase bíblica aplicada por los jesuitas mismos a su universidad.

La suma de los tres edificios, con independencia de sus respectivas cualidades artísticas e interés arquitectónico — que se decantarían, sin duda, por el del Seminario Mayor, obra de Martorell- manifiestan en la montaña de La Cardosa, a su vez, otra memoria no menos poderosa y eficaz que la de las laderas y colina de Sobrellano, si bien aquí, claro es, cambia radicalmente el programa emprendido y sus plasmación arquitectónica.

Estamos, en definitiva, ante una inusitada, sorprendente y abrumadora, no sólo por lo meramente extensivo, ocupación del lugar frontero del palacio, ya en las últimas estribaciones del territorio antes de descender inevitablemente a las orillas del mar, con la pretensión lograda de erigir en él, proceso paralelo al programa laico de enfrente, una auténtica fortaleza de la fe, una ciudad materialmente sobrenatural sobre el altozano, visible desde cualquier distancia, también desde el mar, con una potencia tal debida en parte, y reforzada, por su radical soledad monumental, que evoca la memoria de su linaje, progenie de la arquitectura europea de occidente, expresándolo en los mismos términos del conocido estudio de W. Braunfels sobre la arquitectura monacal en occidente ${ }^{15}$.

Si prescindimos por un instante de la confusión de los términos y nos dejamos aconsejar por la evidencia de las imágenes, así como por la valoración crítica de los contenidos, poco nos importa que lo que se alza sobre el montículo costero de

15 W. Braunfels: «Arquitectura monacal en occidente». Ed. Barral. Barcelona 1975. 


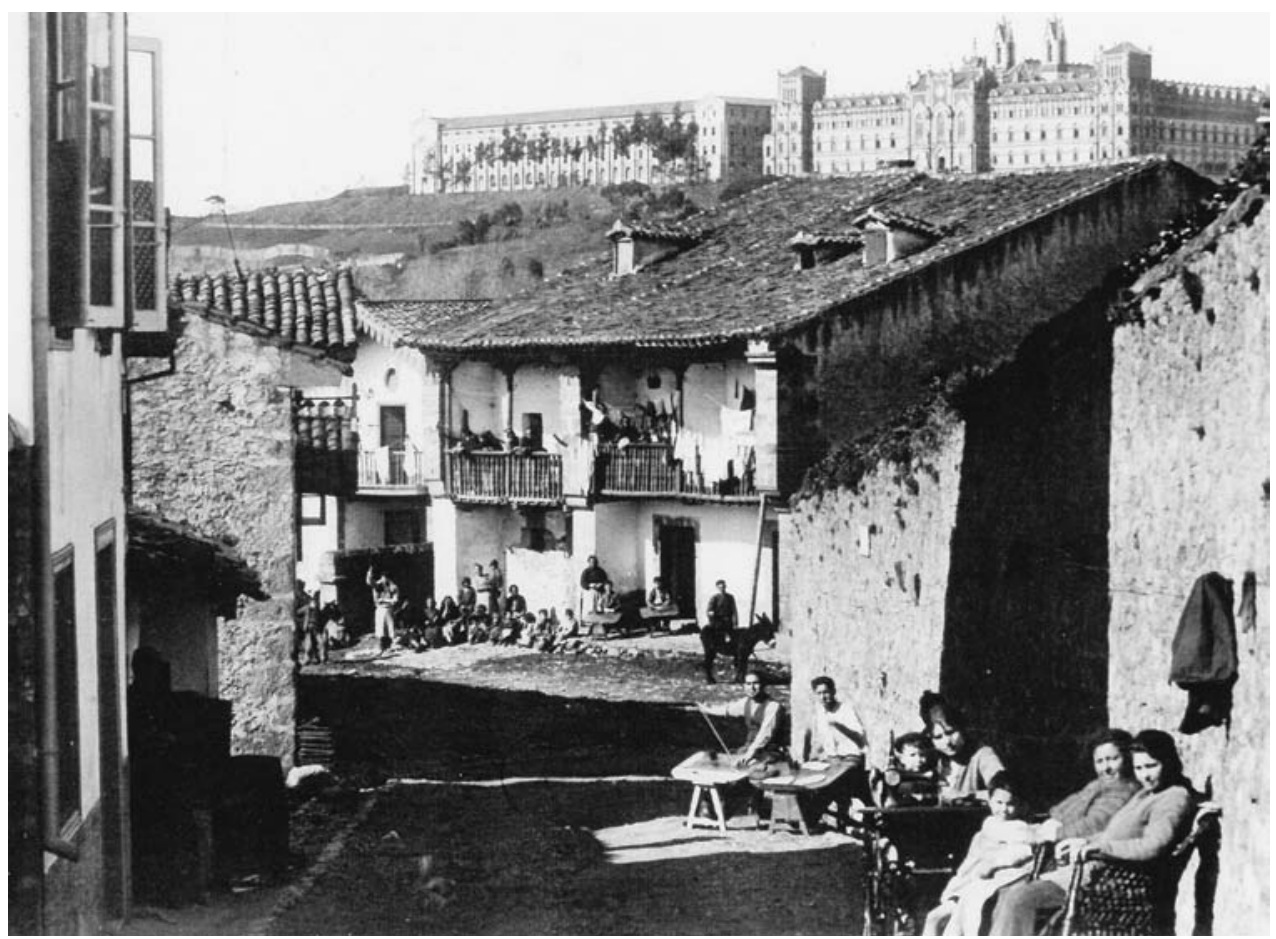

Comillas. Foto histórica del casco urbano tradicional y al fondo el Seminario Pontificio.

La Cardosa responda a la denominación de Seminario, si se entiende perfectamente, y mejor, dentro de la tradición de la arquitectura monacal. Guarda con ésta, desde sus orígenes, una semejante querencia por la elección del lugar. La mayoría de los monasterios gozan de una situación privilegiada, pues los lugares de paisaje extraordinario ya atrajeron desde la más temprana Edad Media a los fundadores, al igual que la belleza de un paraje solitario. El resultado de lo dicho está en una serie incomparable de arquitecturas monumentales al aire libre, en plena naturaleza, siendo al mismo tiempo testimonio de las múltiples formas de vida altamente civilizadas que se desarrollaron en el campo.

Pero no sólo la belleza del paraje solitario es proclive a la reflexión meditativa y al estudio, propio de la vida monacal. Hacia 1600 se impone en occidente el deseo generalizado de que las prelaturas de los monasterios adquirieran las formas y las dimensiones de los palacios. De esta manera, el monasterio pasa a convertirse en un símbolo material de la perfección. Sus patios, los cuerpos de los edificios componentes, sus galería, destacan la iglesia soberana reinante en una ciudad divina, trasunto del ideal que concibe al monasterio como la realización del 
ideal de San Agustín de la «Civitas dei» en la tierra, y «a través de él el orden del mundo, el orden del estado y el orden del monasterio habían de aparecer como dominados por los mismos principios» ${ }^{16}$.

En el ideal agustiniano de la «Civitas dei» se da la coexistencia de dos ciudades, una temporal, carnal, terrestre, y la otra eterna y espiritual. Los monjes habitantes de la «Civitas terrena spiritualis» lo hacen con la finalidad de lograr convertir al mundo de acuerdo con la voluntad divina. El monasterio pretende, pues, el equilibrio entre la «Civitas dei» y la «Civitas terrena», y, según había dejado reglado San Benito, conseguirlo alcanzando a vivir en una ciudad ideal autárquica.

A través de la decisiva y modélica experiencia de El Escorial, en la arquitectura monacal de la Europa central, a partir de 1600, se vuelven a recuperar los programas de reconciliación del Sacerdocio e Imperio, muestra de lo cual será el esplendor arquitectónico de las «kaisersaal» de tantos de sus monasterios ${ }^{17}$. Pero persiste en la idea del monasterio, por muy rico que sea el programa desarrollado, su carácter de isla inaccesible al mundo, utópico, o mejor todavía, ucrónico, como aclara el citado Germain Bazin ${ }^{18}$, en tanto que las vastas extensiones construidas en las cimas de las colinas parecen flotar fuera del tiempo y del espacio, existir al margen y para «sorpresa» del «topos» y del «chronos». Cerrazón la suya en la cual los hombres-monjes-pecadores viven con la esperanza aportada por la Encarnación y su correlativo, la Redención, de manera que en el interior de sus muros el espíritu se desliza imperceptiblemente a lo irreal y a lo onírico. Afectados allá arriba por la misma pasión de construir que alcanzó a Comillas, vieja obsesión de los soñadores de ciudades ideales. Afección constructiva en cuanto actividad demiúrgica, en cuanto ilusión infantil y soberbia de imitar al Creador. Construir, en definitiva, contra la fuerza disolvente de las ideas, de los ideales religiosos que, de todas maneras, acabarán yéndose fantasmalmente, dejando en silencio y en derrumbe las otras construcciones (materiales, extensas) que trataron en vano de retenerlos. Es el discurso de los muros de piedra levantados rozando las nubes, dando pie en la historia a obras maestras imperecederas.

Para que ello fuera domésticamente viable, la ciudad-monasterio-autárquica se sirve de explotaciones agropecuarias que garantizan su autonomía económica y de servicios, como una perfecta conjunción de funciones urdidas para que la eficacia fuera la mayor al menor coste posible.

Casi todos los monasterios, émulos de la «Civitas dei» por antonomasia, la Jerusalén terrenal y celeste, ocupan lugares sobre colinas o peñones desde donde

16 W. Braunfels, op. cit. pag. 255.

17 Germain Bazin «Les palais de la foi. Le monde des monastères baroques». Fribourg 1981.

18 Germain Bazin, op. cit. pg. 10. 


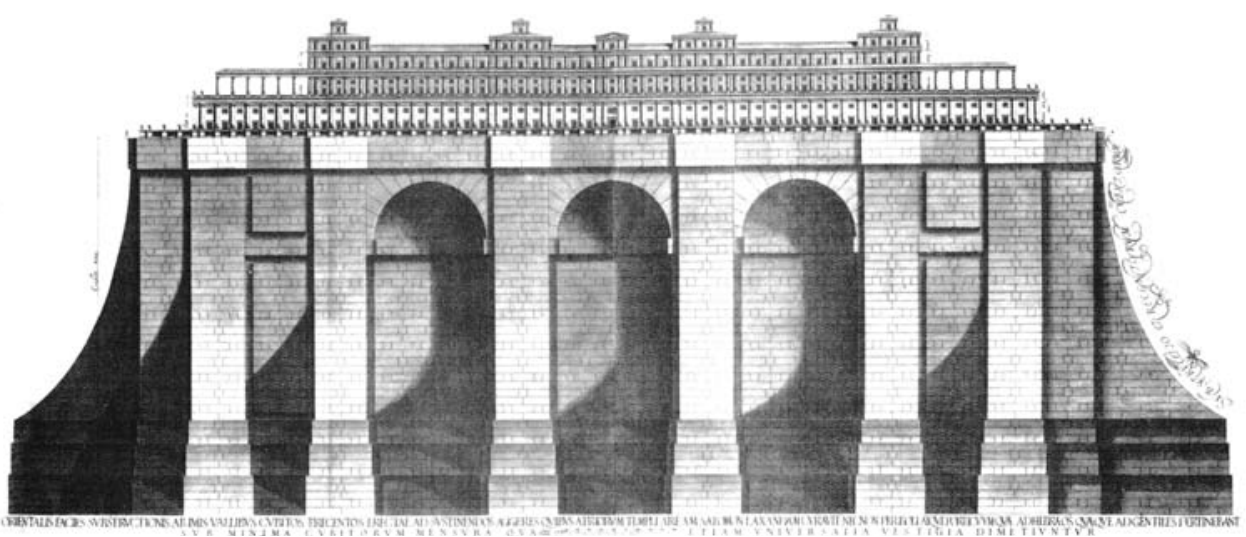

Templo de Salomón según J. B. Villalpando (1596-1606).

dominar su territorio, de manera que la naturaleza sirve y encomia su transformación metamorfoseada en arquitectura simbólica. Se encuentran en dichos monasterios no sólo las huertas y los jardines de plantas medicinales y aromáticas, sino que muchos de ellos aprovechaban los inagotables motivos de los jardines típicamente cortesanos para conferir a la parte edificada unos campos de acceso hermosos y bien estructurados.

La Jerusalén celeste, con variaciones, cabía ser replicada formalmente en la vida terrenal, pues había sido entrevista y descrita en conocidos pasajes bíblicos, particularmente en la visión del profeta Ezequiel (40-44), así como en el texto del historiador judeo-romano Flavio Josefo “Antigüedades judiacas» ${ }^{19}$. Jerusalén, pues, identificada con la construcción del templo salomónico por excelencia, sobre el monte Moria. El templo como tal, divinamente inspirado, prefiguraba la iglesia fundada por Jesucristo, simbolizando la perfección en el orden teológico y en el cosmológico.

Respecto a las variaciones formales del templo sobre el monte Moria es fundamental la aportación de dos padres jesuitas españoles, Jerónimo de Prado (1547-1595) y Juan Bautista Villalpando, (1552-1608) quienes, basándose en Ezequiel, publicaron en Roma, entre 1596 y 1606, los tres volúmenes, profusamente ilustrados, de sus comentarios al Libro del profeta Ezequiel «Hieronymi Pradi et loannis Baptistae Villalpandi e Societate lesu in Ezechielem Explanationes et Apparatus Urbis, ac Templi Hierosolymitani».

\footnotetext{
19 Juan Antonio Ramírez et alt. «Dios arquitecto». Siruela. Madrid 1991.
} 
De esta manera conseguían de una vez por todas unir la tradición bíblico-salomónica y la vitruviana, fundir en una el origen divino de los órdenes, en cuanto éstos habían resultado un regalo de Dios a (su) templo. Los jesuitas proponían una prácticamente «definitiva» reconstrucción del templo, considerado como arquetipo de todo edificio espléndido. La publicación de los jesuitas Prado y Villalpando había sido financiada, no sin reticencias, como parte de la política cultural de la corte de Felipe II, y se enclavaba como un desarrollo del aprendizaje hermético y de la piedad fanática que predominaba en la corte española ${ }^{20}$. De hecho, el padre fray José de Sigüenza (1544-1606), futuro cronista de las obras del monasterio de El Escorial ("La fundación del monasterio de San Lorenzo el Real -1600-, y «Descripción y relación cumplida de todas las partes de la fábrica» -1605-), criticó enérgicamente la versión del templo elaborada por los jesuitas, en particular su enorme extensión y la multitud de atrios «tan fuera de lo que alcanza el brazo y el juicio humano".

Los padres Prado y Villalpando, por su parte, no dejarían de preguntarse cómo fue que el dispendio de tan ingentes caudales por parte de Salomón sólo resultó en un edificio mezquino y desproporcionado, como el que publicó Benito Arias Montano (1527-1598), autor responsable de la famosa «Biblia Regia» (15681572), el último de cuyos volúmenes «Apparatus», incluye sus estudios sobre el templo de Salomón. Montano fue mentor, a su vez, de las posiciones críticas del padre Sigüenza ${ }^{21}$.

Tan espectaculares, o más, que las imágenes del templo de los jesuitas españoles, son las que diseñó, inspirándose directamente en ellos, el célebre arquitecto vienés J. B. Fischer von Erlach que se publicaron como láminas primeras de la reconstrucción de las maravillas de la antigüedad en su importante libro «Entwurff einer historischen Architektur», "Compendio de arquitectura universal», publicado en Viena en 1721. En el alzado del templo, el monte Moria entero es una pura arquitectura fortificada, a cuyos pies la de Jerusalén queda francamente minimizada. En la plataforma de la reconstrucción, que es la cima del monte Moria, las amplias fachadas exteriores del templo se despliegan con «enorme extensión y multitud de atrios", como describía críticamente el padre Sigüenza. Del centro del conjunto de patios, a la manera «escurialense», emergía sobresaliente el volumen de la iglesia, tabernáculo del templo, de la "Civitas dei» de nuevo visionada y proyectada con plena confianza por parte de Fischer von Erlach.

20 Juan Rafael de la Cuadra Blanco, «El Escorial y el Templo de Salomón», Revista «Anales de Arquitectura», n 7, Valladolid 1996.

21 René Taylor: «Juan Bautista Villalpando y Jerónimo de Prado: de la arquitectura práctica a la reconstrucción mística», en J. A. Ramírez et alt. "Dios Arquitecto», op. cit. pag. 182, y del mismo autor, «Arquitectura y magia. Consideraciones sobre la idea de El Escorial». Ed. Siruela. Madrid 1992. 


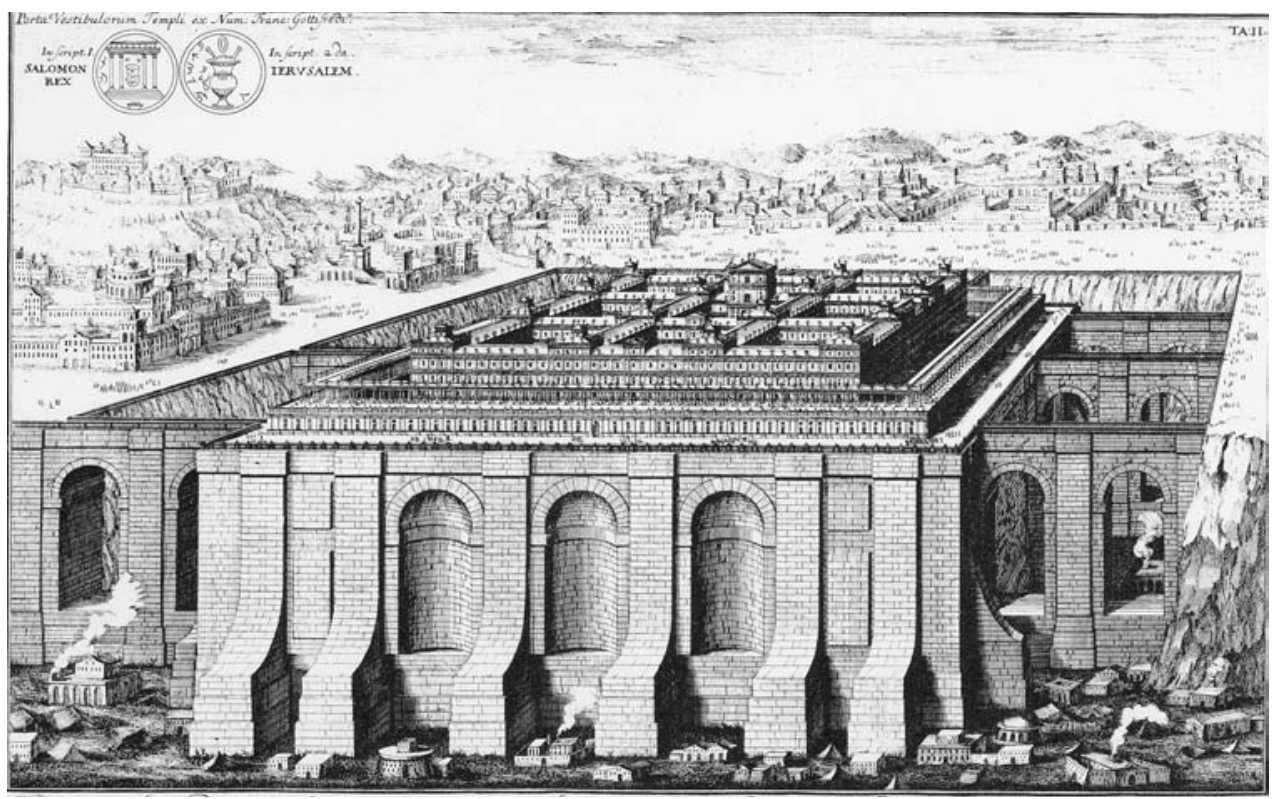

Templo de Salomón según J. B. Fischer von Erlach (1721).

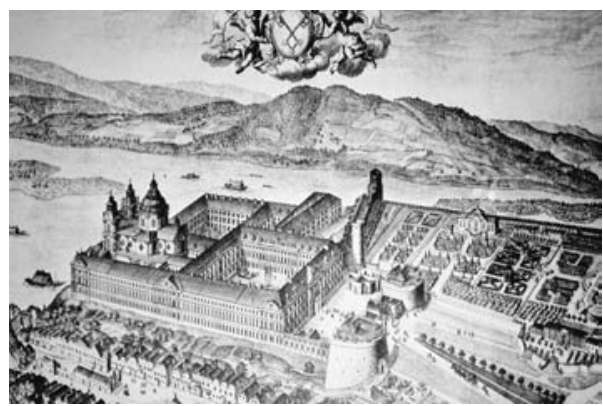

J. Prandtauer. Abadía de Melk, junto a río Danubio, en Austria (1702-1714).

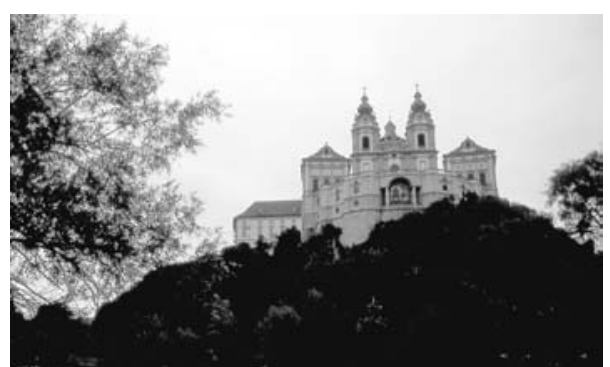

J. Prandtauer. Abadía de Melk, junto a río Danubio, en Austria (1702-1714).

Fischer pertenece a un tiempo de visiones y de ensoñaciones arquitectónicas bastante verosímiles, también de grandes realizaciones monásticas en las tierras centroeuropeas contrarreformistas, con abades principescos y arquitectos cultos nada arredrados ante la incitación de construir monasterios espectaculares, parecidos a coronas dominando el paisaje. Ese fue el caso de Melk, donde el abad Berthold Dietmayr (1670-1726), nombrado abad en 1700, y el arquitecto Jakob 


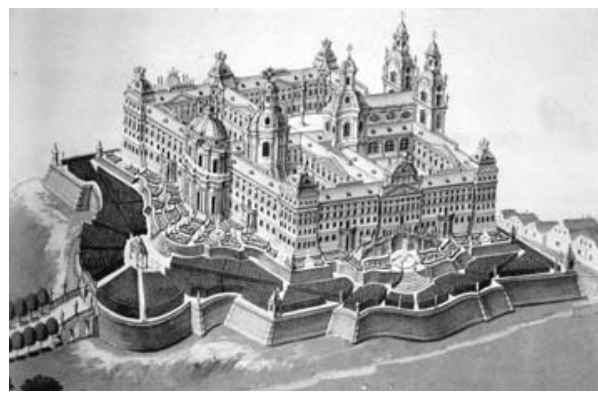

Representación ideal del monasterio de Klosterneuburg, en Austria, según una acuarela de J. Knapp de 1774.

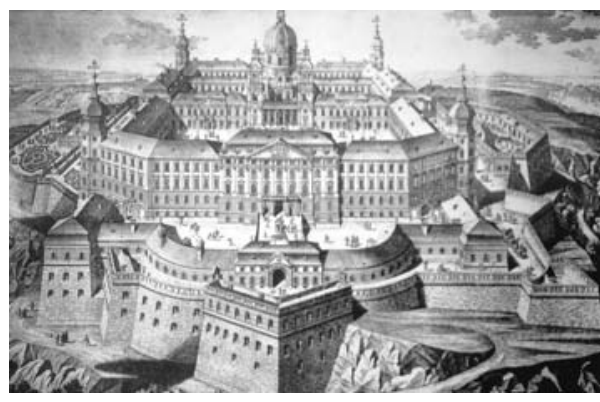

L. Von Hildebrandt. Monasterio de Götweig, Austria (1718).

Prandtauer (1660-1726) transforman el viejo monasterio medieval en una grandiosa composición sobre la masa rocosa incrustrada en el curso del río Danubio. Melk es monasterio de solemne fachada sobre los farallones del río, y es también biblioteca, sala imperial residencial, "kaisersaal», e iglesia, de un lujo artístico impresionante en su interior, asomándose esbelta al paisaje desde su propio belvedere con forma de grandiosa serliana.

O el caso del monasterio también benedictino de Göttweig, el llamado «Montecassino austriaco» proyectado por Lukas von Hildebrandt (1668-1745), arquitecto coetáneo de Fischer von Erlach, que aplicó a la montaña sus conocimientos de la arquitectura de fortificaciones y propuso en la cima de la colina un programa que conjuntaba necesidades que iban mucho más allá de las solicitudes de la vida cenobítica ${ }^{22}$. Se quería, efectivamente, que el conjunto pareciese una corona dominando la amplitud del paisaje, un amplio campo de visión desde las alturas del nuevo monte Moria austriaco. Centro de estudios, residencia monacal y principesca, arquitectura de la cultura cosmopolita trasladada en cuerpo y alma a parajes que refuerzan sus ya de por sí espectaculares argumentos. Pero traslación también en el tiempo, que por medio de exégesis artísticas y teológicas intermedias, muy sofisticadas, como hemos referido, buscaban cristalizar la memoria de una Jerusalén celeste y bíblica, de una completa y cerrada "Civitas dei», en el solar mundano, y desde él, por medio de su evidente monumentalidad manifiesta, irradiar el saber y la fe por la faz de la tierra.

No es casual que en el contenido de la interpretación del Seminario de Comillas como genuina "Civitas dei» jesuítica, adquiera a lo largo de su desarrollo constructivo la misma característica que enervaba al padre Sigüenza respecto a la

22 W. Braunfels, op. cit., pag. 267. 
versión del templo de los padres jesuitas Prado y Villalpando: su enorme extensión, fuera de lo que se alcanza tanto al brazo como al juicio humano.

Es el efecto procurado desde la conclusión del primero de los edificios de la colina comillense, sucesivamente reduplicado y completado con los argumentos intermediados de las experiencias arquitectónicas monacales, de manera que el territorio de la villa queda profundamente marcada con los signos del poder secular simbolizados en los edificios de la colina del palacio y jardines, y del poder religioso enfrente, con la plasmación, que financia el mismo poder secular, del seminario, fantástico sobre la soledad, o mejor, el vacío que llena su artística presencia, no menos culta y cosmopolita, y más rica, incluso, traída y depositada una vez más, de nuevo, en la colina de la fe y de la enseñanza, con el diseño del mismo arquitecto foráneo del palacio.

Vacíos de sus funciones, los edificios agrupados de la antigua universidad monacal evocan las intensas aspiraciones llevadas a lo alto de la colina de La Cardosa, pues como ciudad autárquica requería de los servicios variados, agropecuarios, hortofortículas, a la manera tradicional de los grandes monasterios, de manera que el programa posee sorprendentes elementos de interés patrimonial añadidos a los específicamente «artísticos» de las intervenciones originales de Martorell, Cascante y Doménech, como es el caso de la ascensión hacia la explanada desde la monumental puerta de acceso, sólo que aquí el tratamiento de

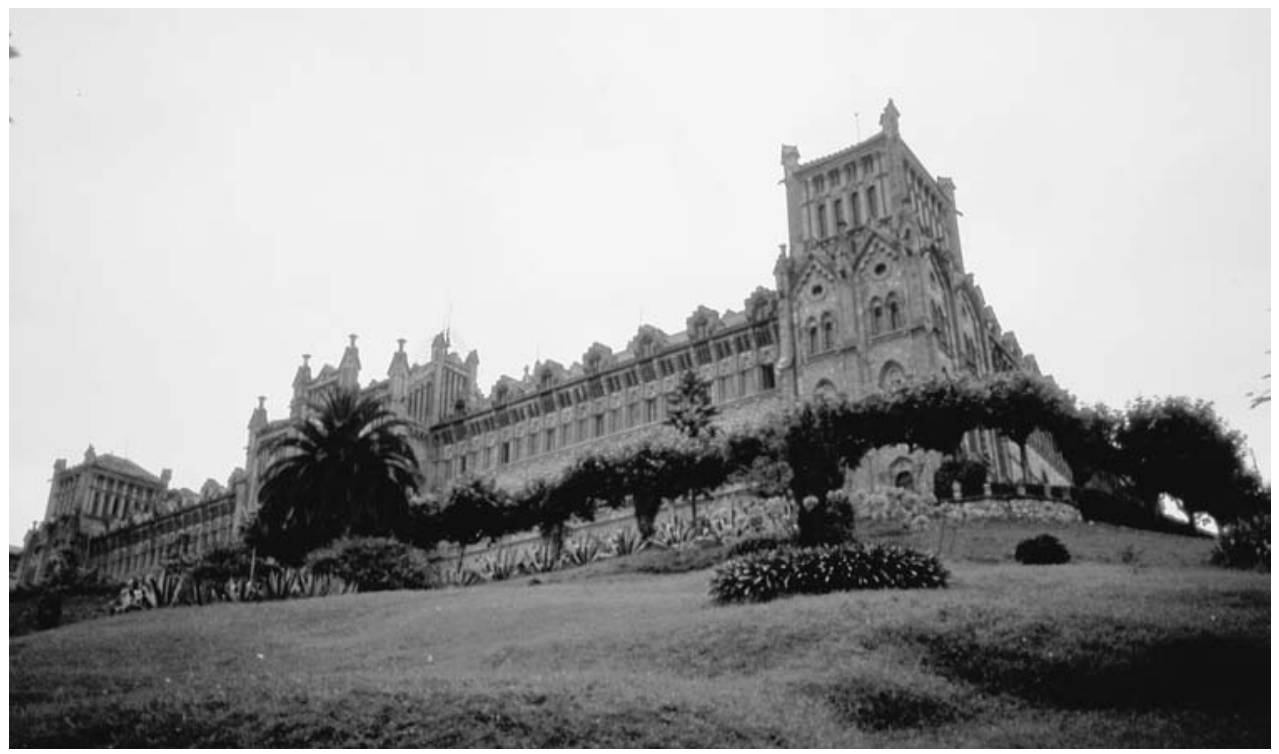

Seminario Pontificio. Aspecto actual del edificio original (1889) y del entorno de su jardín. 
la base del seminario-monasterio, en cuanto enésima variación del monte Moria, se lleva a cabo ya no con los recursos abastionados de los ejemplos aludidos, sino con otros de diluida raíz jardinera, en consonancia con las líneas generales generadas desde el jardín y parque del palacio de Sobrellano. Dado que forman, como decimos, partes no escindibles de un único programa ejecutado con la suficiente continuidad temporal y de criterios como para no dejar de pasar desapercibido.

Una última observación final respecto a la consideración de las referencias históricas en la colina universitaria. La villa de Comillas tampoco deja de participar en la premeditada construcción de un paisaje simbólico. Como en la imagen de Fischer von Erlach, Comillas rodea y ampara, cual Jerusalén terrenal, la montaña del templo. Si se respetan todas las reglas de la referencia, cada parte debe ocupar la debida posición relativa, sin traspasar los límites ni las distancias de las distintas esferas, para no quebrar la armonía de las mismas, y así, Jerusalén terrenal, debe estar siempre sólo en la base, y ninguna otra cosa debe perturbar la contundente definición formal y simbólica de la arquitectura superior, «supra montem posita», pensada y cerrada así desde su proyectación original y la luego continuada, verdadero hito monumental en el paisaje costero de la región que le sirve con sus argumentos naturales y que con la cultura arquitectónica queda él mismo transfigurado para siempre.

\section{EL ULTIMO ARGUMENTO: UN CEMENTERIO MARINO DE RAIZ ROMANTICA}

La más profundamente religiosa de las obras del ciclo comillense, la reforma del cementerio, fechada en 1893, que responde al proyecto de LL. Doménech i Montaner, nos conmueve por lo que posee de profunda llamada de atención a lo más inexcusablemente espiritual del ser humano: la muerte.

La elección del campo santo a la orilla riscosa del Cantábrico cuenta con su propia leyenda popular, que en definitiva deviene desde la ruina de la antigua iglesia tardogótica solitaria a una lectura e intervención en clave de evocadora ruina romántica. Ruina de una iglesia que forma parte del paisaje arquitectónico de un cementerio, ruina como pura imagen de la desolación, también de la naturaleza como aposento genuino de la más viva de las creencias. Ruina de iglesia que el arquitecto Doménech i Montaner perfora y consolida al mismo tiempo, dejándola en esa elocuente imperfección, abriéndola a la vez al vasto horizonte marítimo, naturaleza ampliada con visos de infinitud, alusión a la prolongación intemporal del descanso eterno. 


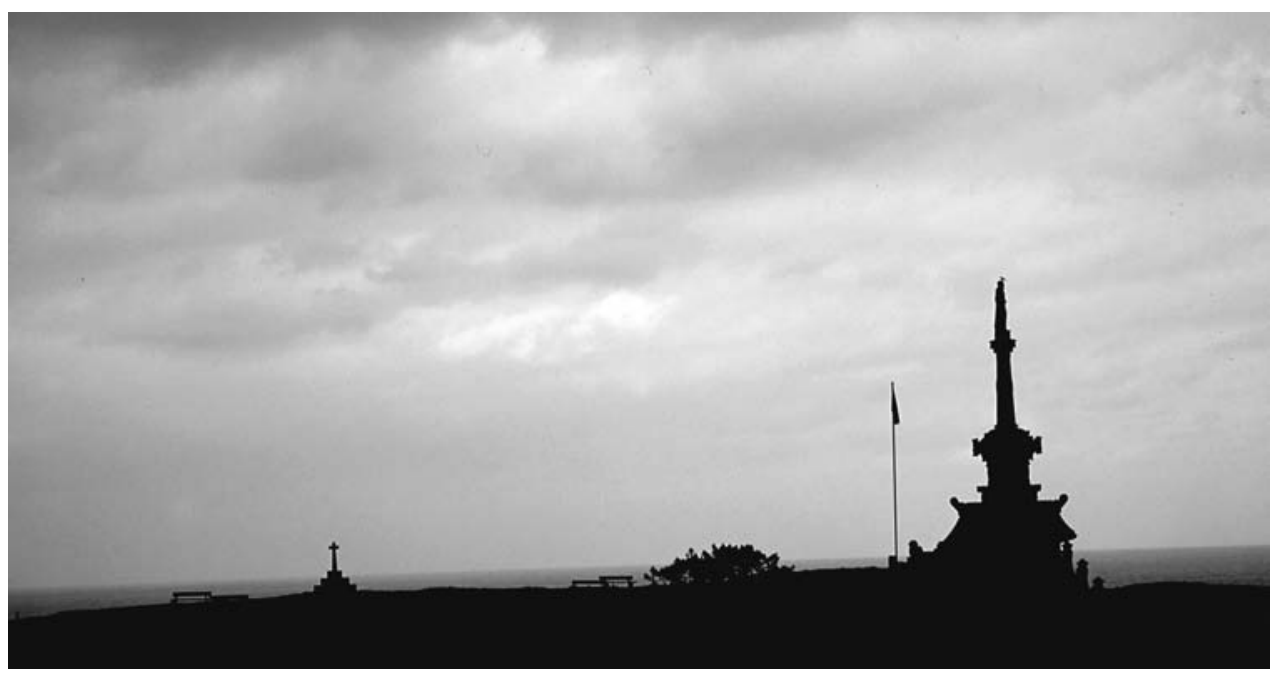

Comillas. Perfil del borde del parque con el monumento al marqués de Comillas (1889) y cementerio en la cornisa marítima.

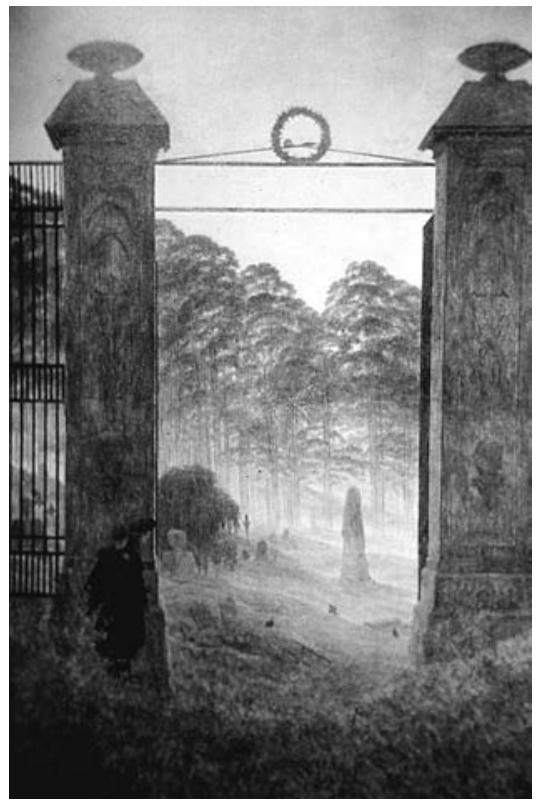

C. D. Friedrich «Puerta del cementerio» (h. 1825).

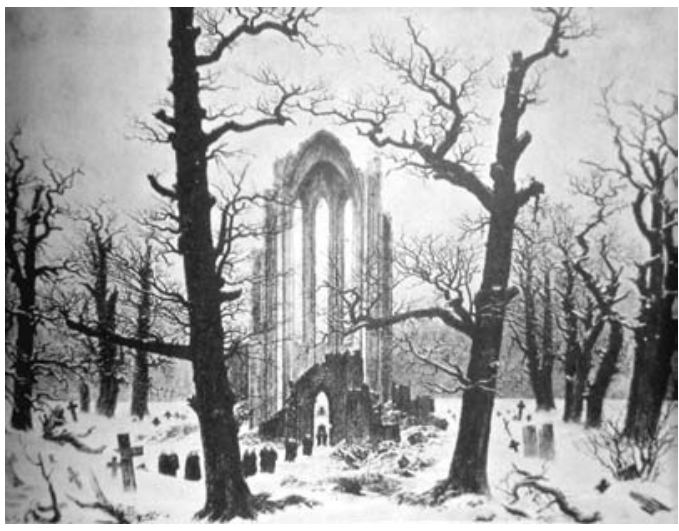

C. D. Friedrich. "Cementerio monástico en la nieve» (1817-1819). 
No resulta habitual en la tradición católica española la imagen de un cementerio tan próximo al panteísmo romántico de raíz europea septentrional, pues estamos más cerca de las ruinas pictóricas de C. D. Friedrich, de las ruinas de las abadías en los robledales germanos, o en las colinas escandinavas de la meditación, que son paisajes arquitectónicos sublimados por el saber de un profundo y melancólico G. Asplund, cercanos igualmente a las islas fúnebres de A. Böcklin: su «Isla de los muertos», de 1880, sin embargo llevó inicialmente el título significativo de «Lugar tranquilo».

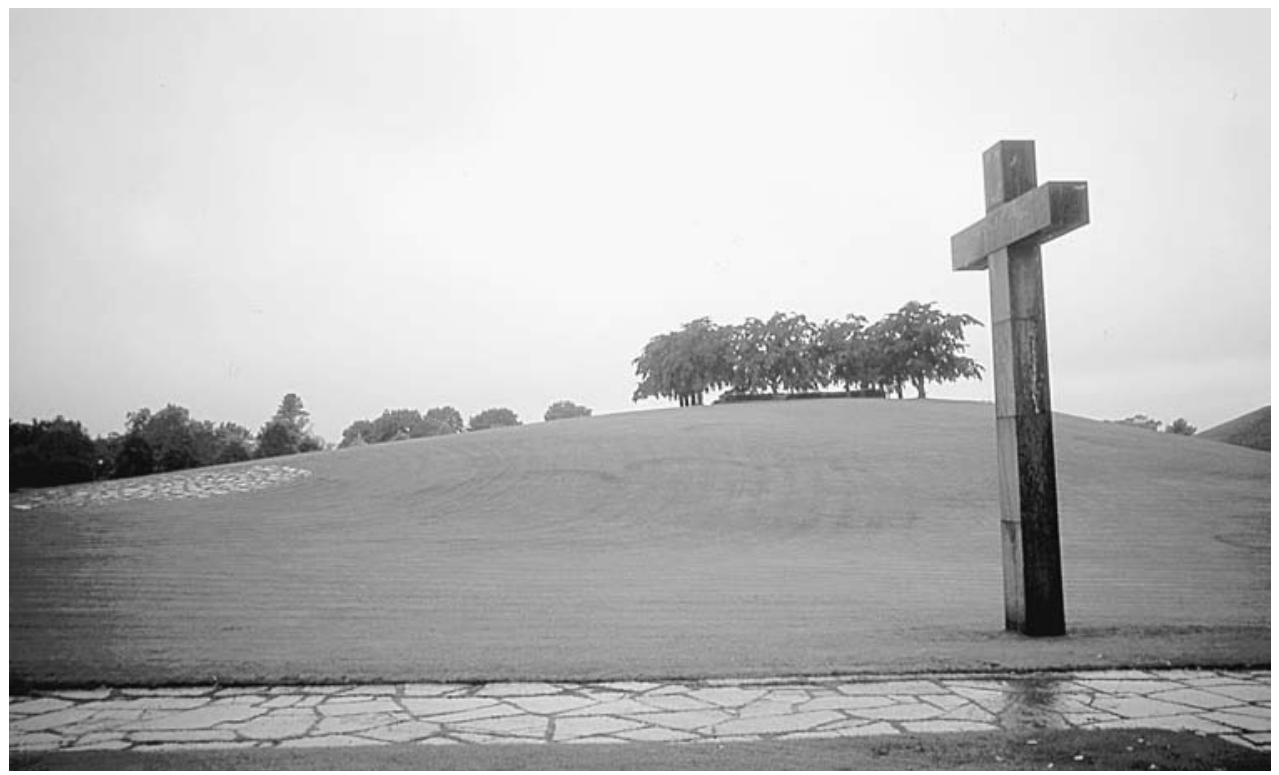

G. Asplund. Estocolmo. Cementerio de Skogskyorgarden (1917-1940).

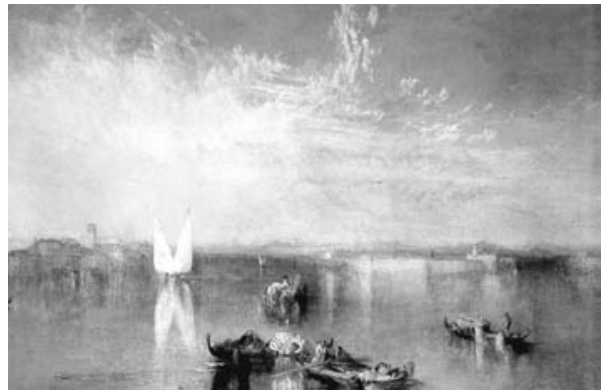

J. M. W. Turner. «Campo Santo. Venecia» (1842).

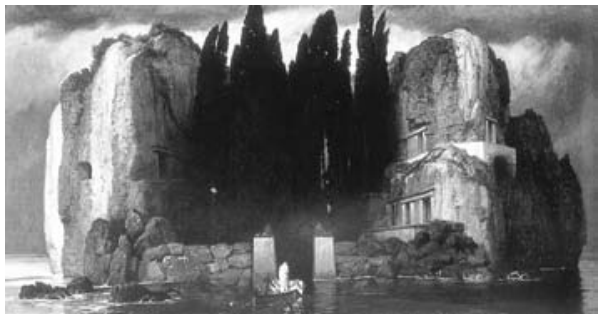

A. Böcklin. "La isla de los muertos", originalmente «Un lugar tranquilo» (1880). 
Quizá haya que acudir a la pintura para entender mejor el profundo contenido de la intervención de Doménech i Montaner en el cementerio de Comillas, o recurrir a Venecia de nuevo, para hallarnos con una realidad física, la pequeña isla de San Michele, no menos operativamente transmutada a principios del siglo diecinueve por el arquitecto Antonio Selva en una «isla cementerio» que cumple el expreso deseo de la joven viuda que le encargó a Böcklin la que sería su pintura más famosa: poseer «un cuadro para soñar».

La intervención en la ruina consolidada como cementerio incluye el muro perimetral de mampostería, fragmentado para adaptarse a la pendiente, rematado por cruces sobre pináculos sobre contrafuertes embutidos en el muro, destacando igualmente la puerta monumental de acceso, muy decorada, recortada intencionadamente para abrir las vistas del interior del recinto. Pero, sobre todo, el proyecto de Doménech i Montaner, casi llevado a la realidad constructiva literal según su dibujo, incluye y se completa con la memorable figura del ángel solitario, pues el autor había previsto y dibujado dos, el segundo reclinado a los pies del victorioso «ángel guardián» único realizado. El ángel fue debido al trabajo, de excelente factura, de Josep Llimona, que también será autor del de la tumba-panteón de Joaquín del Piélago, dentro del propio cementerio, pero dispuesto con visión tan pictórica y arquitectónica por Doménech, como muestra el referido dibujo del proyecto fechado en agosto de 1893.

Ángel guardián y temible de mármol blanco, ángel blanco de alas desplegadas al viento cual velas o alas de ave marina, ángel justiciero de la muerte y de su recordatorio trascendente, ángel para ser evocado por siempre desde la tierra y desde el piélago, protagonista decidido que determina de manera peculiar el lugar, no sólo anunciando la riqueza escultórica en túmulos y mausoleos dentro del ce-

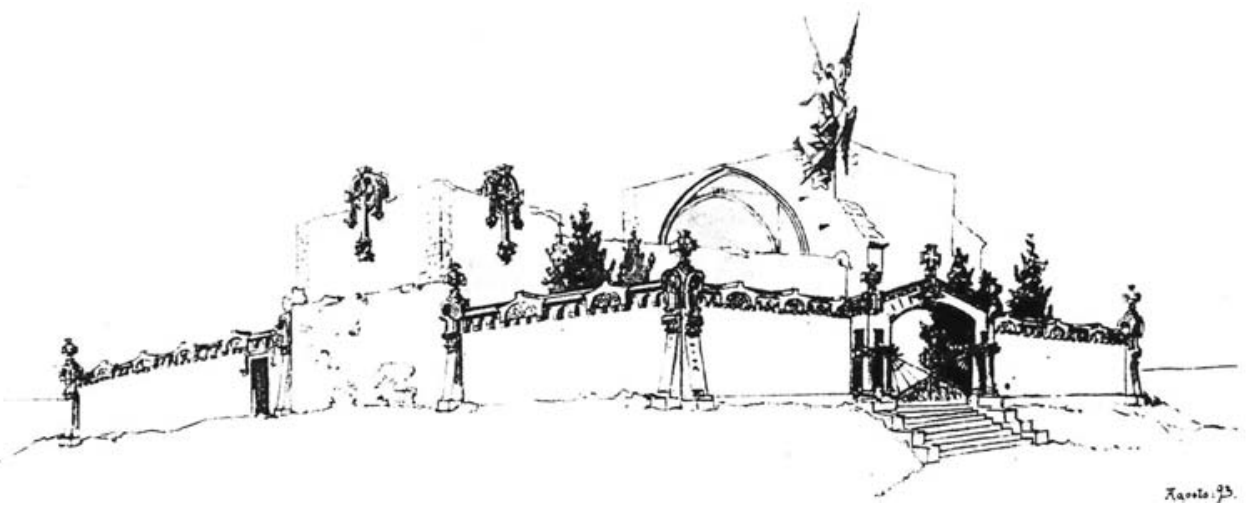

LL. Domenech i Montaner. Dibujo del cementerio de Comillas (1893). 
menterio, sino que recalca con inusitada fuerza presencial y simbólica una intervención de Doménech i Montaner, limitada en los recursos aparentes empleados, pero plena de intencionalidad y ecos de cultura elevada.

Ese manso techo donde andan las palomas,

Entre pinos palpita, entre tumbas;

El justo mediodía hace allí fuegos

¡El mar, el mar, siempre vuelve sobre sí!

(...)

Después de tanto orgullo y tanta extraña

Ociosidad, plena de poder,

Me abandono al brillante espacio,

Sobre las casas de los muertos mi sombra pasa

Y me somete a su frágil movimiento

(PAUL VALÉRY. «El cementerio marino»)

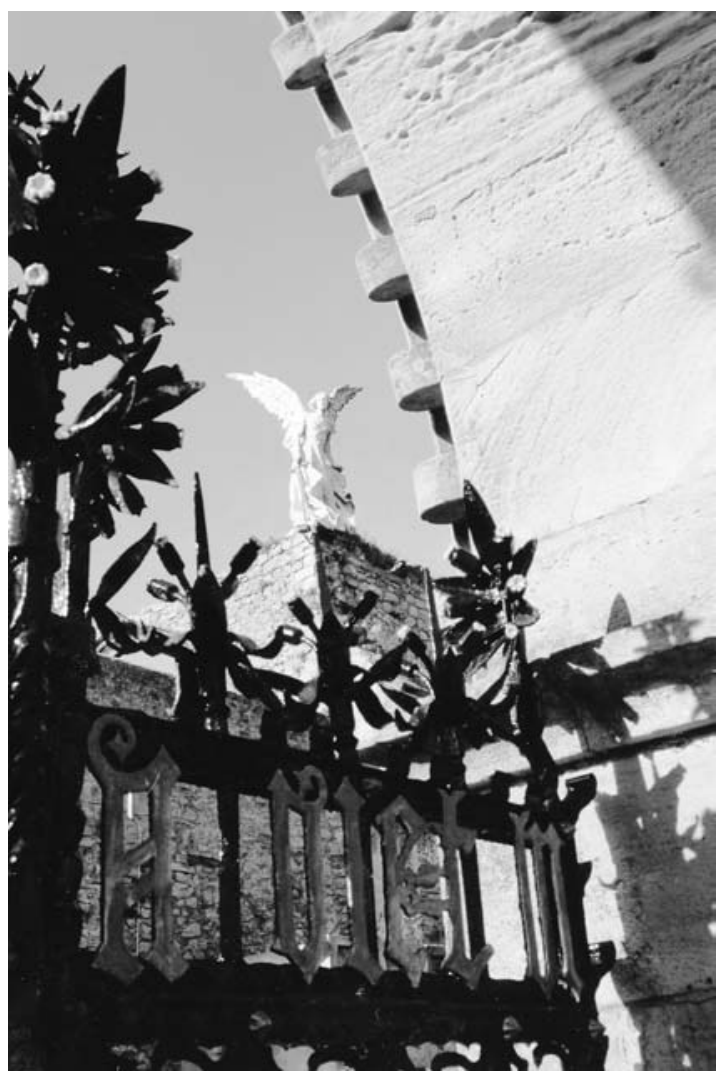

Comillas. Aspecto parcial del cementerio con el ángel de J. LLimona. 
Un cierre reformado con cruces sobre pináculos, puertas y vanos abiertos en la ruina, vegetación y ángeles mortuorios, severos y melancólicos. Y de nuevo el paisaje. El mar. El lugar de la memoria y de la contemplación, tanto como valor religioso cuanto como pura actitud estética. Por todo ello, el dibujo de Doménech del cementerio, presume un amplio ámbito de soledad necesaria, distancia que hacia el interior de la villa salvaguarda el monumento del primer marqués con su vacío de verde, obra igualmente de Doménech. El dibujo, decimos, resulta pleno y delicioso, y sumamente descriptivo del "aire» del lugar, nos recuerda ineludiblemente temas pictóricos, y sustenta con ello, como único soporte "científico» necesario, suficiente, la discretísima intervención proyectual.

Ruinas tardomedievales, mausoleos, enterramientos, cementerios marinos. La soledad extrema. Y el mar. Habría que retrotraerse al monje de C. D. Friedrich, o de nuevo a sus abadías ruinosas en los robledales, para parangonar a la altura debida el cementerio de Comillas.

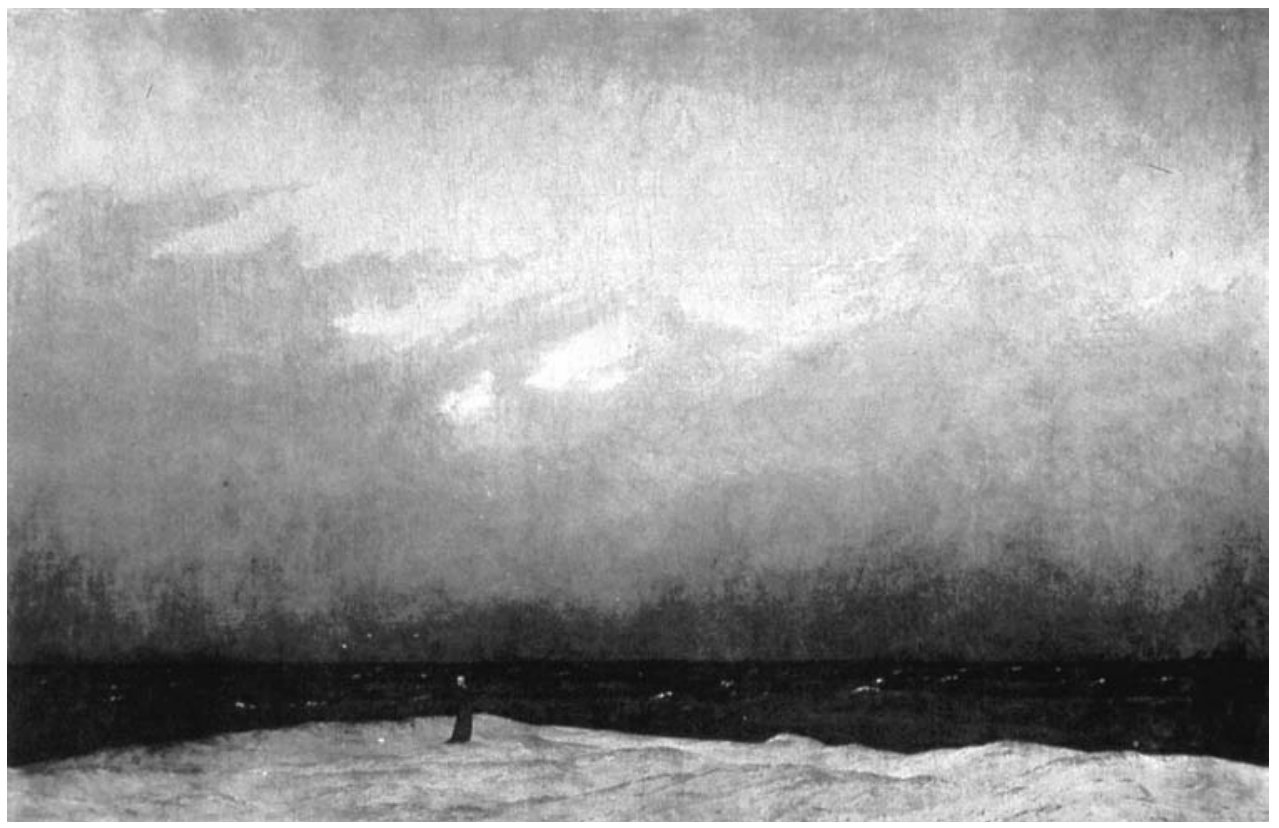

C. D. Friedrich. «Monje en soledad a la orilla del mar» (1808-1810). 


\section{NOTA FINAL: VALORACION DE COMILLAS COMO PAISAJE CULTURAL}

Comoquiera que el texto anterior forma parte de una colaboración de un trabajo en equipo, ganador de un concurso previo del cual resultó la redacción del Plan General de Ordenación Urbana y Plan Especial de Protección del Casco Urbano entre los años 2001 y 2003 (equipo dirigido por el arquitecto Eduardo Ruiz de la Riva), y siendo que por la naturaleza de dicho trabajo se requiere el acompañamiento de prescripciones, se ha preferido en la presente ocasión deslindarlo del cuerpo más puramente historicista del estudio, pero no hasta el punto de prescindir del mismo. Porque, siendo su carácter diferente al habitual de los estudios de los historiadores del arte, sin embargo, se incardinan con el texto descriptivo de la arquitectura de Comillas, tanto las proposiciones sobre actuaciones, como recomendaciones sobre como prolongar de la manera más feliz posible la tradición con el desarrollo de la villa. Ello resulta particularmente importante en actuales tiempos de rápidas intervenciones y fáciles acomodos, en los que el plano se ha convertido en un documento referencial sobre el que inscribir las apetencias de un fácil y tantas veces catastrófico crecimiento oportunista de las ciudades, sin mas consideraciones estéticas o cualquiera de las nociones de belleza que estuvieron formando parte de la cultura urbana en el mundo culto civilizado hasta tiempos relativamente recientes. Por esas y tantas otras lógicas razones, se ha mantenido, si bien en un segundo plano de la narración, las recomendaciones derivadas del propio estudio, que son las siguen a continuación.

Por todo lo anterior, se entiende que, de la misma manera que en la actual cultura paisajístico-arquitectónica, todo lo citado respecto a la villa de Comillas constituye una oferta de bien cultural, el cual conforma substancialmente su propia imagen urbana, moviéndose su actual estado entre el cuidado, la desidia o el abandono. Por ello es necesario, a partir de su entendimiento como un valor positivo y dinámico, intensificar la conciencia de su oportuna presencia y tratar de garantizar su preservación y mantenimiento según su reconocida valoración como bien arquitectónico y paisajístico-ambiental de la villa. En ello han de participar los propios vecinos y propietarios, pero con el reconocimiento, defensa y ayuda de las demás partes implicadas en los procesos urbanos, más teniendo en cuenta que habitualmente se sobreentiende como patrimonio aquel directamente vinculado con aspectos monumentales o de prestigio, en tanto que las permanencias y legados de carácter anónimo o popular son poco observados o desconsiderados, dejados sin regular.

Además se une, en el caso de Comillas, el peligro de focalización exclusivista en los temas y apartados decididamente históricos de su catálogo monumental: Palacio, «Capricho», Seminario, Cementerio... Lo cual está harto justificado, pero ello no ha de implicar el olvido o descuido del resto de la villa, que merece una detenida y atenta mirada, para pasar a valorar, mantener y preservar sus genuinos 
valores propios, tanto desde el punto de vista arquitectónico, espacial, como paisajístico y ambiental, tanto en lo que atañe a construcciones de mayor enjundia, casas, jardines, especies arbóreas, parques..., como a los pequeños pero significativos detalles constructivos: muros, recodos, espacios residuales tratados, huertos, mobiliario urbano etc. etc.

De los argumentos anteriores se deriva la vital importancia que posee, y debe mantener, el conjunto de las partes que constituyen el parque de Sobrellano, entendido como una unidad cultural arquitectónico-paisajística indisoluble. Los efectos preservativos legales amparan sólo a los edificios singulares -Palacio, Capilla y «El Capricho»- que parecen tener garantizada su continuidad, al menos desde el punto de vista material, pues no consideramos el controvertido asunto del destino funcional y métodos proyectuales de restauración de los edificios catalogados como patrimonio cultural. El mantenimiento de los mismos resulta oneroso, como todo lo que afecta al patrimonio en general. Es cierto que no siempre la conservación a ultranza debe considerarse como la decisión más acertada en cada caso, pero debe también observarse al respecto que bastante se ha destruido ya, y que, pareciendo responder a una regla maldita y no deseable, en general, lo que sustituye suele ser peor que lo sustituido. Por eso, el antídoto es seguir aquel precepto jansenista, el cual, ante la posibilidad de no alcanzar a hacer el bien en términos absolutos, recomendaba que al menos debía tratarse de evitar el mal.

Intervenir y preservar el patrimonio cultural —arquitectónico/paisajísticocomo es el caso que nos ocupa, no consiste sólo en mantener y hacer perdurables los edificios como contenedores vacíos, sino que, en cuanto propuesta cultural obligatoriamente incluye la previsión de su uso y los medios de su mantenimiento posterior. Si no se rompe la tendencia a preocuparse sólo de lo primero, restaurar y preservar el patrimonio cultural se limitaría tan sólo a aliviar la agonía de dulces enfermos terminales que acabarán difuminándose y arrastrando tras de sí la estela de su recuerdo y de las vivencias colectivas que, con ellos, hasta entonces, se habían mantenido en pie.

Desde esta convicción difícilmente refutable, la propuesta en el caso del parque de Sobrellano, pasa, en primer lugar, por reconocer y asumir que éste, espacialmente, está constituido por tres partes unidas en continuidad pero diferenciables según su conformación histórica y existente:

— jardines bajos de los entornos arquitectónicos de los «monumentos»

- «parque romántico» con vegetación boscosa y fábricas arquitectónicas cultas en su circuito,

- colina adyacente, básicamente un «vacío» de prados y pinares, que «abren» las perspectivas hacia el paisaje exterior y se constituye como la 
mejor transición entre el paisaje interior y exterior de la villa, así como también en un espléndido observatorio de la villa, muy a propósito para ser recreado como un paseo ajardinado de cariz arquitectónico moderno.

Dicho parque histórico unitario debe preservarse según la naturaleza histórica original que hemos definido, ligado al trazado de los edificios de los que ha venido formando parte como unidad integral. Esto afecta tanto a los ajardinamientos bajos de las zonas próximas a las construcciones (parterres de césped, terrazas, rampas, muretes de ataludamiento, elementos escultóricos ornamentales, etc.) así como también el juego de vacíos y llenos espaciales de los prados, césped y boscajes formados por especies arbóreas de alto porte, lo cual, aún en el estado de semiabandono actual, evoca con claridad su linaje de parque romántico creado con plena intención y conciencia de tal por su principal responsable, el segundo marqués de Comillas. La atención del lugar supone, por supuesto, el conocimiento de las especies arbóreas que conforman la plantación, extensible a criterios equivalentes de restauración botánica.

Pero no sólo las consideraciones afectan al tratamiento preventivo y restaurador del parque a fin de devolverle a su imagen original y pudiendo ser el gran y prestigioso parque que la villa de Comillas necesita como elemento verde en el interior de su propio espacio urbano, sino que deben ser restaurados y devueltos a su función estético-ornamental los elementos materiales que poblaban el recorrido del mismo - gruta artificial, ruinas, ninfeo, canales acuáticos-así como, en consonancia con lo anterior, debe ser reedificado en el lugar original, el templete clásico rotondo, punto de vista fundamental de Comillas y elemento de reconocibilidad del parque y de la villa, como atestiguan y corroboran las imágenes fotográficas que dan testimonio de su relevante papel en la conformación espacial culta de la villa.

El valor arquitectónico de los edificios del Seminario Pontificio no guarda equidad, pues se reparte en proporción inversa a su modernidad. Las fachadas de los tres han terminado por incorporarse en cuanto «corona de la ciudad», según la feliz expresión del arquitecto expresionista alemán Bruno Taut, a la silueta de una segunda «reconocibilidad» monumental de Comillas. Además de la singularidad de sus respectivas masas, en su ámbito se ubican otros de menor porte pero igualmente singulares, caso del frontón, pero donde también se incluye el hoy tristemente abandonado cementerio, íntimamente ligado a las construcciones de la colina, parte ampliada del jardín superior sobre el que se alza el Seminario.

La consideración de toda la montaña como soporte espacial, simbólico, compositivo y paisajístico de las construcciones superiores, de esta ambiciosa y anacrónica "civitas dei», como la hemos denominado, no ofrece lugar a dudas sobre su destino y conservación lo más íntegra posible, lo más ajena posible a cualquier 
vecindad constructiva laica, como fue su ideación originaria. Ello incluye los puntos de vista alejados de la «montaña sagrada», esto es, el valor visual referencial que el seminario posee desde variadas distancias, incluidas las más remotas, pero sobremanera la más próxima y acechada por intereses espúreos: la colina frontera, el pinar arbolado y las praderías que hemos señalado como parte del parque de Sobrellano.

La base de la colina de la Cardosa no posee un trazado geométrico sofisticado, ni responde a una ideación compositiva cerrada, y con el tiempo se le han incorporado arquitecturas residenciales unifamiliares que han distorsionado su límpida observación, tendencia que de ninguna manera debe consentirse so pena de destruir la potente empresa que alzó en tal sitio una de la más ambiciosas construcciones de la arquitectura monacal española de los dos últimos siglos. En esa dirección deben entenderse las actuaciones, preservando con claridad los elementos de transición desde la base, la puerta monumental, hacia la plataforma que sirve de aposentamiento al Seminario, pasando por el recorrido ajardinado tanto del acceso como de la parte superior, e incluyendo en ello también el cementerio, que debe ser atendido en su justa necesidad.

En definitiva, toda la colina de este Seminario se entiende como un espacio libre, construido tanto en términos arquitectónicos como de ajardinamiento y de visuales próximas, medias y lejanas, con fuertes componentes simbólicas, de contundente fuerza monumental y trascendencia referencial a escala nacional e internacional, de lo que se deriva su calificación como espacio de especial protección, según los valores históricos, simbólicos y paisajísticos señalados, donde ha de prohibirse cualquier edificación de cualquier tipo, salvo elementos puntuales ligados a dicho espacio protegido y los asimilados a las propuestas de los volúmenes del Seminario según se define en este mismo documento.

El estudio del caso del cementerio de Comillas no puede entenderse espacial y paisajísticamente separado de las demás partes que se unen y completan su «lectura» particularizada. Entendemos que esas partes constitutivas están formadas por:

- parque y monumento del marqués de Comillas

- casa y jardín de la finca del duque de Almodóvar

- cementerio y entorno exterior inmediato

Cada una de ellas se han visto sometidas a someras o profundas alteraciones, tanto en lo que se refiere a sus propias composiciones, como a las derivadas de actuaciones en sus inmediaciones - apertura de calles y vías rápidas de circulación, a veces de infeliz y desmesurada implantación, como la rotonda vial que agrede al cementerio y ha cambiado substancialmente su imagen desde la franja 
costera, o las casas familiares del borde de la vía de acceso, insultantemente evidentes con su chillona policromía y su falso historicismo estilístico, de manera que consiguen hacer «amable» y discreta la implantación del bloque de viviendas de pescadores que ocupa la hondonada que separa el parque y monumento del cementerio.

Respecto a cada una de las partes de esta unidad paisajística, entendemos que, preservándose la entidad de la casa y jardín del la finca del duque de Almodóvar como ingrediente consolidado en esta parte de la imagen de Comillas, en lo que afecta a espacios públicos, el parque del monumento del marqués de Comillas ha de ser reconsiderado en su calidad de parque paisajístico, pues la sola presencia del monumento no debe conducir a la falsa convicción que es indiferente lo que se proponga a su alrededor; de esa manera se seguirían justificando un inadecuado parque de juegos infantiles o el indolente diseño de bancos, luminarias, etc. que no responden en absoluto a la altura de consideraciones arquitectónicas y paisajísticas de tan importante espacio y ubicación.

En lo que se refiere al cementerio, monumento de amplia fama, como lo atestigua su nivel de repercusión bibliográfica, se propone no sólo su consideración como tal, de manera que la brillante intervención de Doménech i Montaner sobre la ruina gótica, al igual que la de las partes escultóricas señaladas, y otras, se consoliden como parte de este paseo pintoresco de la costa comillense, devolviéndole a las consideraciones de ocupación previstas en los cálculos iniciales.

Esto supone el «vaciamiento» de una situación actual que lo sobresatura y lo desvirtúa de sus hermosas pretensiones, pero da pie y deja abierta una no menos hermosa idea: la proyectación de un nuevo cementerio próximo en el espacio y en la idea compositiva, formal y pictórica del domenechiano, en los términos más arriba indicados, de manera que el parque ajardinado se ampliaría notablemente, «limpiando» la parte costera afectada, que llegaría por el camino de la costa hasta la punta de la Moria con un más adecuado tratamiento de este atractivo paseo, todo tan acechado en los últimos años. De esta manera tan noble se ofrecerían inequívocas señales de la conciencia de que la tradición y la modernidad se constituyen como la doble argumentación armonizada que guía y conduce a Comillas desde el devenir hacia su destino. 